University of New Hampshire

University of New Hampshire Scholars' Repository

9-2002

\title{
Modeling seasonal to annual carbon balance of Mer Bleue Bog, Ontario, Canada
}

\author{
Steve Frolking \\ University of New Hampshire - Main Campus, steve.frolking@unh.edu \\ Nigel T. Roulet \\ McGill University \\ Tim R. Moore \\ McGill University \\ P M. Lafleur \\ Trent University \\ Jill L. Bubier \\ Mount Holyoke College
}

See next page for additional authors

Follow this and additional works at: https://scholars.unh.edu/earthsci_facpub

\section{Recommended Citation}

Frolking, S., N. T. Roulet, T. R. Moore, P. M. Lafleur, J. L. Bubier, and P. M. Crill, Modeling seasonal to annual carbon balance of Mer Bleue Bog, Ontario, Canada, Global Biogeochem. Cycles, 16(3), doi:10.1029/ 2001GB001457, 2002.

This Article is brought to you for free and open access by the Earth Sciences at University of New Hampshire Scholars' Repository. It has been accepted for inclusion in Earth Sciences Scholarship by an authorized administrator of University of New Hampshire Scholars' Repository. For more information, please contact Scholarly.Communication@unh.edu. 
Authors

Steve Frolking, Nigel T. Roulet, Tim R. Moore, P M. Lafleur, Jill L. Bubier, and P Crill 


\title{
Modeling seasonal to annual carbon balance of Mer Bleue Bog, Ontario, Canada
}

\author{
Steve Frolking, ${ }^{1}$ Nigel T. Roulet, ${ }^{2}$ Tim R. Moore, ${ }^{2}$ Peter M. Lafleur, ${ }^{3}$ Jill L. Bubier, ${ }^{4}$ \\ and Patrick M. Crill ${ }^{1}$ \\ Received 9 July 2001; revised 10 February 2002; accepted 18 February 2002; published 4 July 2002.
}

[1] Northern peatlands contain enormous quantities of organic carbon within a few meters of the atmosphere and play a significant role in the planetary carbon balance. We have developed a new, process-oriented model of the contemporary carbon balance of northern peatlands, the Peatland Carbon Simulator (PCARS). Components of PCARS are (1) vascular and nonvascular plant photosynthesis and respiration, net aboveground and belowground production, and litterfall; (2) aerobic and anaerobic decomposition of peat; (3) production, oxidation, and emission of methane; and (4) dissolved organic carbon loss with drainage water. PCARS has an hourly time step and requires air and soil temperatures, incoming radiation, water table depth, and horizontal drainage as drivers. Simulations predict a complete peatland $\mathrm{C}$ balance for one season to several years. A 3-year simulation was conducted for Mer Bleue Bog, near Ottawa, Ontario, and results were compared with multiyear eddy covariance tower $\mathrm{CO}_{2}$ flux and ancillary measurements from the site. Seasonal patterns and the general magnitude of net ecosystem exchange of $\mathrm{CO}_{2}$ were similar for PCARS and the tower data, though PCARS was generally biased toward net ecosystem respiration (i.e., carbon loss). Gross photosynthesis rates (calculated directly in PCARS, empirically inferred from tower data) were in good accord, so the discrepancy between model and measurement was likely related to autotrophic and/or heterotrophic respiration. Modeled and measured methane emission rates were quite low. PCARS has been designed to link with the Canadian Land Surface Scheme (CLASS) land surface model and a global climate model (GCM) to examine climate-peatland carbon feedbacks at regional scales in future analyses. INDEX TERMS: 1615 Global Change: Biogeochemical processes (4805); 0305 Atmospheric Composition and Structure: Aerosols and particles (0345, 4801); 1890 Hydrology: Wetlands; 9350 Information Related to Geographic Region: North America; KEYWORDS: peatland,

decomposition, NPP, NEE, carbon accumulation, model

\section{Introduction}

[2] Relative to other ecosystems, northern peatlands have low rates of annual net primary productivity (NPP) [Thormann and Bayley, 1997], decomposition [e.g., Bartsch and Moore, 1985; Johnson and Damman, 1993; Belyea, 1996], and net $\mathrm{CO}_{2}$ exchange [Frolking et al., 1998], but over millennia, NPP has been greater than decomposition. Hence northern peatlands have been a persistent sink for $\mathrm{CO}_{2}$, averaging $20-30 \mathrm{~g} \mathrm{CO}_{2}-\mathrm{C} \mathrm{m}^{-2} \mathrm{yr}^{-1}$ over the past $5000-$ 10,000 years [Gorham, 1995; Tolonen et al., 1992]. This has resulted in $200-450 \mathrm{Pg} \mathrm{C}(15-30 \%$ of total world soil

\footnotetext{
${ }^{1}$ Institute for the Study of Earth, Oceans, and Space, University of New Hampshire, Durham, New Hampshire, USA.

${ }^{2}$ Department of Geography and Centre for Climate and Global Change Research, McGill University, Montreal, Quebec, Canada.

${ }^{3}$ Department of Geography, Trent University, Peterborough, Ontario, Canada.

${ }^{4}$ Department of Earth and Environment, Mount Holyoke College, South Hadley, Massachusetts, USA.
}

Copyright 2002 by the American Geophysical Union. 0886-6236/02/2001GB001457 carbon) being sequestered in a total peatland area of $\sim 3.5$ million $\mathrm{km}^{2}$ [Gorham, 1991; Turunen et al., 2002], 10\% of the total non-ice-covered land area north of $45^{\circ} \mathrm{N}$. In many regions of Canada, Finland, and western Siberia, peatlands can occupy $>50 \%$ of the landscape. Despite the large quantity of carbon that peatlands contain, they generally have been ignored in global biogeochemistry and ecosystem modeling efforts. This is largely due to the difficulty of modeling peatland hydrology. In previous work we have described how we have parameterized [Letts et al., 2000] and evaluated [Comer et al., 2000] the Canadian Land Surface Scheme (CLASS) [Verseghy, 2000] for peatland ecosystems. The second step in the assessment of response of the carbon stored in peatlands to climate change has been to develop a process-based ecosystem model that could be coupled to CLASS and used in climate simulation studies. In this paper we discuss the development, evaluation, and sensitivity of this model, the Peatland Carbon Simulator (PCARS). PCARS links directly to the recently developed Peatland Decomposition Model, which simulates long-term peat accumulation [Frolking et al., 2001]. 
[3] Slow decomposition rates in northern peatlands result from the combined effects of limited oxygen diffusion into saturated peat leading to anoxic conditions for a large portion of the peat profile [Clymo, 1992], the generally cool temperatures of peat due to the large heat capacity of wet peat and the low thermal conductivity of moss [Roulet et al., 1997], and the inherent resistance to decomposition of some peatland vegetation tissues, particularly Sphagna [e.g., Johnson and Damman, 1993; Hogg, 1993]. Since soil moisture and temperature partially control the slow decomposition, $\mathrm{C}$ sequestration rates in peatlands are susceptible to change with a changing climate [Gorham, 1995]. Climate change is expected to be greatest at high latitudes, where most peatlands are located [Kattenberg et al., 1996]. These latitudes also contain discontinuous permafrost, and climate change induced permafrost degradation [Anisimov et al., 1997] could result in shifts in peatland hydrology, which is the dominant control of peatland maintenance. Thus there is a need to understand and be able to predict the carbon balance of northern peatlands under current and projected conditions. In the first year-round eddy covariance carbon balance study on a northern peatland in North America, Lafleur et al. [2001] found net annual sequestration rates of $\sim 60 \mathrm{~g} \mathrm{C} \mathrm{m}^{-2} \mathrm{yr}^{-1}$, higher than would be expected based on long-term accumulation of $\sim 25 \mathrm{~g} \mathrm{C} \mathrm{m}^{-2} \mathrm{yr}^{-1}$. They cannot yet conclude if this was due to favorable weather conditions in the measurement year or represents a real shift in peatland net ecosystem exchange of $\mathrm{CO}_{2}$ (NEE) toward higher sequestration, perhaps due to ongoing nitrogen deposition, $\mathrm{CO}_{2}$ fertilization, and/or some other factor.

[4] In addition to their role as a carbon reservoir, peatlands and other wetlands are the only natural terrestrial ecosystems that are a significant source of $\mathrm{CH}_{4}$ to the atmosphere, contributing $\sim 20 \%$ of the total global input [Prather et al., 1995]; northern peatlands comprise one third of the natural wetland source [Bartlett and Harriss, 1993]. The dominant controls on rates of methane emission from peatlands include soil climate and vegetation composition/trophic status [e.g., Bubier et al., 1995; Frolking and Crill, 1994].

[5] Apps et al. [1993] identified uncertainty in contemporary carbon budgets of northern peatlands as one of the largest remaining gaps in our assessment ability of circumpolar boreal carbon budgets. There have been few ecosystem carbon models developed specifically for peatlands and only a few cases of generalized ecosystem models being applied to peatlands. Alm et al. [1999] developed an empirical model based on statistical regressions between growing season $\mathrm{CO}_{2}$ flux, as measured weekly by static flux chambers, and biophysical variables such as peat temperature, water table depth, and solar radiation. By monitoring these biophysical variables continuously throughout the growing season at a bog in eastern Finland, a seasonal estimate of $\mathrm{CO}_{2}$ flux was obtained. Carroll and Crill [1997] developed a similar, sitespecific empirical model for a small fen in New Hampshire, U.S.A. Trumbore et al. [1999] applied this same approach to estimate a growing season carbon balance for a peatland complex in northern Manitoba, Canada, and compared the result to an estimate of mean annual carbon accumulation over the past several decades derived from high-resolution radiocarbon dating of the peat profile and to net ecosystem productivity (NEP) based on measured aboveground net primary productivity and total soil respiration. Potter et al. [2001] applied a process-based ecosystem model, NASACASA, to the same Canadian peatland site. The NASACASA model can function across a range of ecosystem types; for the wetland simulations, it was modified to include run-on from the surrounding uplands and a moss groundcover, simulating both $\mathrm{CO}_{2}$ and $\mathrm{CH}_{4}$ exchange. Rivers et al. [1998] developed an empirically based stochastic model to estimate the net carbon balance and its uncertainty for the Rapid River Watershed in Minnesota, U.S.A. Using a Monte Carlo technique to randomly sample from distributions of input parameters (e.g., dissolved carbon concentration in precipitation), drivers (e.g., annual precipitation), and processes (NEE), Rivers et al. [1998] derived a distribution of estimates of the net carbon balance of the large peatland complex. Their study is the only one to include inputs and outputs of dissolved organic carbon (DOC) and dissolved inorganic carbon (DIC) in the peatland carbon budget.

[6] In this paper we present a new peatland ecosystem model, PCARS (Peatland Carbon Simulator), developed in conjunction with ongoing field studies at Mer Bleue Bog near Ottawa, Canada [Lafleur et al., 2001]. Like the NASA-CASA model, PCARS is process based; PCARS has been designed in a generalized form that should be suitable for all northern peatlands. PCARS parameterization included one set of parameters typical of northern bogs (e.g., decomposition and photosynthesis functions) and a second set representing the Mer Bleue site (e.g., vegetation type and biomass). Model output was compared with measurements of $\mathrm{CO}_{2}$ exchange by eddy covariance tower over a 2 -year period. Model parameter sensitivity studies were run to evaluate which processes and parameters should receive the most attention in future field and laboratory studies. Because peatland respiration depends on the amount and decomposability of the accumulated peat, the peat profile in PCARS is initialized with a second model, Peatland Decomposition Model (PDM) [Frolking et al., 2001], ensuring that the peat profile is generally consistent with the productivity, tissue decomposability, and mean water table depths of the contemporary site. This links contemporary carbon fluxes with long-term peat accumulation, a new feature in peatland ecosystem models.

\section{PCARS Model}

[7] PCARS simulates the carbon balance $\left(\mathrm{CO}_{2}, \mathrm{CH}_{4}\right.$, and DOC) of a peatland over seasonal to multiyear time periods (Figure 1). It includes submodels to (1) initialize the entire peat profile based on a long-term mean accumulation [Frolking et al., 2001], (2) simulate hourly vegetation photosynthesis and respiration, (3) simulate hourly aerobic and anaerobic decomposition down the peat profile, and (4) simulate daily, seasonal, and annual vegetation phenology, carbon allocation, NEE, methane, and DOC fluxes from the peatland and to simulate net ecosystem productivity (NEP = $\left.\mathrm{NEE}-\mathrm{CH}_{4}-\mathrm{DOC}\right)$.

\subsection{Vegetation}

[8] PCARS simulates photosynthesis, respiration, phenology, litter production, and NPP individually for five 
PCARS Model Structure

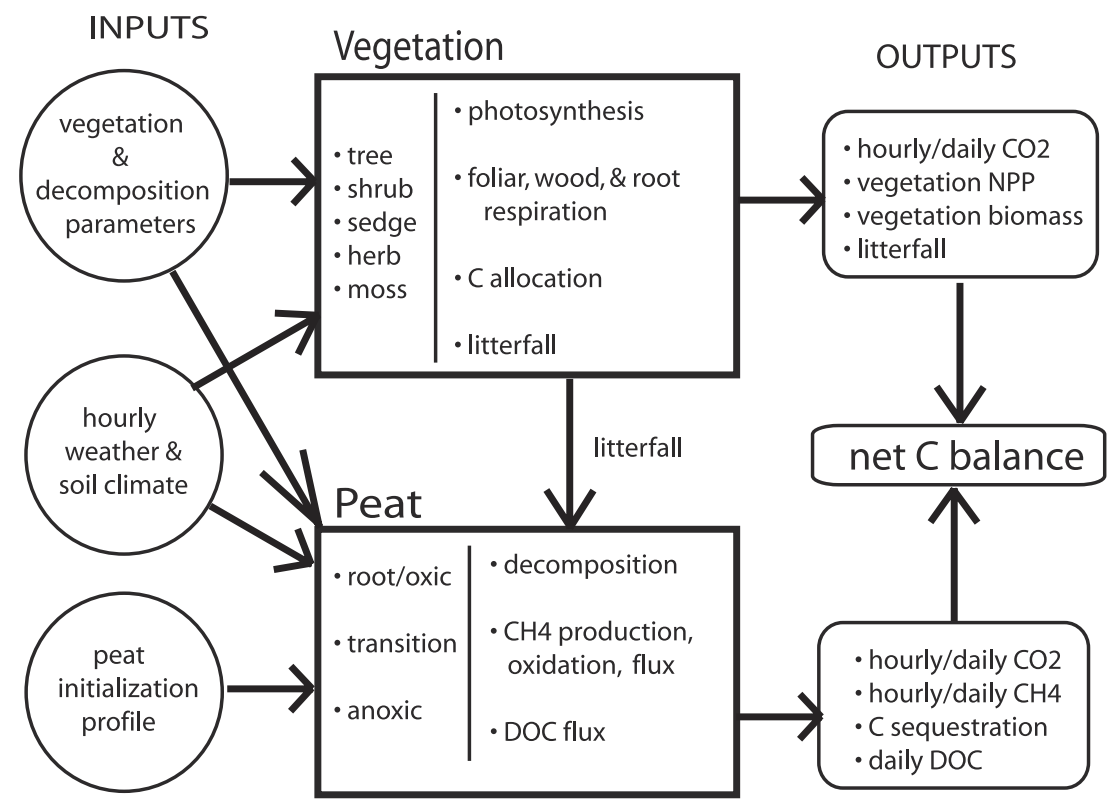

Figure 1. Overview of components of Peatland Carbon Simulator (PCARS) model.

classes of peatland vegetation: trees, shrubs, graminoids (e.g., sedges), other herbaceous vegetation, and mosses. Trees and shrubs can be either evergreen or deciduous. A peatland simulation can include any combination of these vegetation types, though a typical peatland site may only have two or three vegetation classes present in significant quantity.

[9] A primary distinction between the vegetation classes is their height and thus their access to incoming sunlight. The canopy is vertically stratified, with the tree canopy over a combined shrub and graminoid canopy, over a canopy of other herbs, over moss. Incoming photosynthetically active radiation (PAR) is attenuated through each canopy by a Beer's Law exponential extinction [Ross, 1975; Lambers et al., 1998], based on the leaf area index (LAI) of each canopy, calculated from leaf biomass and specific leaf area. Other differences between vegetation types can be maximum and minimum leaf biomass, maximum photosynthetic rate, ratio of aboveground to belowground biomass, amount of nonphotosynthetic respiring tissue (e.g., sapwood), and timing of leaf phenology.

\subsubsection{Photosynthesis}

[10] The basic photosynthetic calculation, $\operatorname{PSN}_{i}$, is a rate per unit mass of active green foliage (including moss) for each vegetation type $i$,

$$
\operatorname{PSN}_{i}=P_{\max , i} f_{i}(T) f_{i}(W) f_{i}(\mathrm{PAR}),
$$

where $P_{\max , i}$ is the maximum photosynthetic rate of vegetation type $i$ (see Table 1 ), $f_{i}(T)$ is a temperature multiplier, $f_{i}(W)$ is a moisture multiplier, and $f_{i}(\mathrm{PAR})$ is a PAR multiplier. The calculation proceeds down the vegetation canopy from the tallest vegetation present to the moss.
[11] A single temperature function is used for all vegetation types [e.g., Titus and Wagner, 1984; Silvola, 1985; Sveinbjörnsson, 1992],

$$
\begin{array}{ll}
f_{i}(T)=0 & T<T_{\min } \text { or } T_{\max }<T, \\
f_{i}(T)=1-\left(\frac{T_{\mathrm{opt}}-T}{T_{\mathrm{opt}}-T_{\min }}\right)^{2.5} & T_{\min }<T<T_{\mathrm{opt}}, \\
f_{i}(T)=1-\left(\frac{T-T_{\mathrm{opt}}}{T_{\max }-T_{\mathrm{opt}}}\right)^{2.5} & T_{\mathrm{opt}}<T<T_{\max } .
\end{array}
$$

For vascular plants, $T$ is air temperature, and for mosses, $T$ is ground surface temperature. $T_{\min }, T_{\text {opt }}$, and $T_{\max }$ are the same for all vegetation types (Table 1).

[12] Vascular vegetation is assumed to generally have access to water so, for all vascular plants, $f_{i}(W)=1.0$, while the water table depth, $z_{\mathrm{WT}}$, is $<0.4 \mathrm{~m}$; below that drops linearly to 0.7 as $z_{\mathrm{WT}}$ increases to $0.8 \mathrm{~m}$ (the maximum water table depth for all simulations in this study). For mosses,

$$
\begin{array}{ll}
f_{i}(W)=0 & W_{i}<W_{\mathrm{min}}, \\
f_{i}(W)=1-\left(\frac{W_{\mathrm{opt}}-W_{i}}{W_{\mathrm{opt}}-W_{\mathrm{min}}}\right)^{2} & W_{\mathrm{min}}<W_{i}<W_{\mathrm{opt}} \\
f_{i}(W)=1-0.5\left(\frac{W_{i}-W_{\mathrm{opt}}}{W_{\mathrm{sat}}-W_{\mathrm{opt}}}\right) & W_{\mathrm{opt}}<W_{i},
\end{array}
$$

where $W_{i}$ is moss water content and values for $W_{\text {opt }}$ and $W_{\text {min }}$ (Table 1) are based on results from Titus and Wagner [1984] and Silvola [1990]. $W_{\text {sat }}$ is the moss water content at saturation. 
Table 1. General Parameters in Peatland Carbon Simulator (PCARS) Model

\begin{tabular}{|c|c|c|}
\hline Parameter & Value & Description \\
\hline$k_{\text {anox }}$ & 0.025 & $\begin{array}{l}\text { rate reduction in decomposition due to anoxia } \\
\quad[\text { Frolking et al., 2001] }\end{array}$ \\
\hline$k_{0}$ (shrub, moss) & $0.2,0.05$ & $\begin{array}{l}\text { initial litter mass loss rate }\left(\mathrm{y}^{-1}\right) \text { [Frolking } \\
\text { et al., 2001] }\end{array}$ \\
\hline$Q_{10, d}$ & 2.0 & $\begin{array}{l}\text { increase in rate of decomposition caused by } \\
10^{\circ} \mathrm{C} \text { increase in temperature [Scanlon and } \\
\text { Moore, 2000] }\end{array}$ \\
\hline$T_{\min }($ decomposition $)$ & -4.0 & minimum temperature $\left({ }^{\circ} \mathrm{C}\right)$ for decomposition \\
\hline$W_{\text {opt }}($ decomposition $)$ & 0.6 & $\begin{array}{l}\text { optimum water-filled pore space for decom } \\
\text { position [Linn and Doran, 1984] }\end{array}$ \\
\hline$T_{\min }, T_{\mathrm{opt}}, T_{\max }$ & $0,20,35$ & $\begin{array}{l}\text { minimum, optimum, and maximum } \\
\text { temperatures }\left({ }^{\circ} \mathrm{C}\right) \text { for photosynthesis [Titus } \\
\text { and Wagner, 1984; Silvola, 1985; } \\
\text { Sveinbjörnsson, 1992] }\end{array}$ \\
\hline$W_{\min }, W_{\mathrm{opt}}, W_{\max }$ & $2,10,20$ & $\begin{array}{l}\text { minimum, optimum, and maximum moss } \\
\text { water content ( } \mathrm{g} \text { water } \mathrm{g}^{-1} \text { biomass) for } \\
\text { photosynthesis [Silvola, 1990; Titus and } \\
\text { Wagner, 1984] }\end{array}$ \\
\hline$P_{\max }$ & $0.00191,0.00044$ & $\begin{array}{l}\text { maximum photosynthetic rates }\left(\mathrm{g} \mathrm{C} \mathrm{g}^{-1} \mathrm{~h}^{-1}\right) \\
\quad \text { for shrub and moss foliage [Small, 1972] }\end{array}$ \\
\hline$\alpha$ & 0.02 & $\begin{array}{l}\text { initial slope of photosynthetic light response } \\
\text { curve [Frolking et al., 1998] }\end{array}$ \\
\hline$k_{\text {beer }}$ & 0.5 & $\begin{array}{l}\text { Beer's Law canopy light extinction factor } \\
\quad[\text { Lambers et al., 1998] }\end{array}$ \\
\hline Base foliar respiration rate & 0.10 & $\begin{array}{l}\text { fraction of gross photosynthesis [Aber and } \\
\quad \text { Federer, 1992] }\end{array}$ \\
\hline$R_{\text {root, } 0}$ & 0.0106 & mol C mol ${ }^{-1} \mathrm{~N} \mathrm{~h}^{-1}[$ Ryan, 1991] \\
\hline$R_{\text {wood, } 0}$ & 15 & $\mu \mathrm{mol} \mathrm{m} \mathrm{m}^{-3} \mathrm{~s}^{-1}[$ Ryan et al., 1995$]$ \\
\hline$(\mathrm{C}: \mathrm{N})_{\text {root }}$ & 45 & Frolking et al. [1996] (black spruce value) \\
\hline$T_{\min }$ autotrophic respiration & 0 & $\begin{array}{l}\text { minimum temperature }\left({ }^{\circ} \mathrm{C}\right) \text { for autotrophic } \\
\text { respiration }\end{array}$ \\
\hline$Q_{10}$ foliar respiration & 2.0 & Aber and Federer $[1992]$ \\
\hline$Q_{10}$ root respiration & 1.8 & Ryan [1991] \\
\hline$Q_{10}$ sapwood respiration & 1.7 & Ryan et al. [1995] \\
\hline $\mathrm{CH}_{4}$ threshold concentration & 1.0 & $\begin{array}{l}\text { maximum dissolved } \mathrm{CH}_{4} \text { concentration } \\
\text { (mmol) before bubble losses occur } \\
\text { [Rothfuss and Conrad, 1994] }\end{array}$ \\
\hline $\mathrm{CH}_{4}$ oxidation zone & $0,0.15,0.3$ & $\begin{array}{l}\text { top, middle, and bottom depths }(\mathrm{m}) \text { of } \\
\text { methane oxidation zone (based on field } \\
\text { observations) }\end{array}$ \\
\hline $\mathrm{CH}_{4}$ production fraction & 0.5 & $\begin{array}{l}\text { fraction of anaerobic decomposition that } \\
\text { goes to } \mathrm{CH}_{4}[\text { Conrad }, 1989]\end{array}$ \\
\hline
\end{tabular}

[13] Photosynthetic response to incoming PAR is modeled as a rectangular hyperbola,

$$
f(\mathrm{PAR})=\frac{\alpha \mathrm{PAR}}{\alpha \mathrm{PAR}+P_{\max }},
$$

with the $\alpha$ parameter fixed at 0.02 for all peatland vegetation [Frolking et al., 1998] and with a vegetationspecific $P_{\max }$ parameter [Small, 1972; Titus and Wagner, 1984]. An $f(\mathrm{PAR})$ value is calculated for each vegetation component for each hour of the day with PAR $>0$. Component vegetation LAI values for a single peatland vegetation class are typically $\sim 1-2$ and thus attenuate the PAR by a factor of $\sim 40-63 \%(\sim \exp (-0.5)$ to $\exp (-1.0))$. Taking this Beer's Law attenuation into account, the value of $f$ (PAR) halfway down a canopy with LAI of $1-2$ is $<1 \%$ different than the mean value of $f(\mathrm{PAR})$ calculated for the same canopy divided into 30 layers. Thus a single calculation is done for each vegetation type using the midcanopy PAR value. For moss, where light extinction is nearly complete within a few centimeters [Skre et al., 1983;
Longton, 1988], the photosynthesis calculation uses a PAR value of $85 \%$ of the value incident on the top of the moss canopy.

\subsubsection{Respiration}

[14] Plant respiration is calculated separately for foliage (all plants), sapwood (trees and shrubs only), and roots (all vascular plants). The base foliar respiration rate was $10 \%$ of $P_{\max }$ [Aber and Federer, 1992] and was modified by an exponential temperature function, with a $Q_{10}$ value of 2.0. Root respiration was calculated as a base rate $\left(R_{\text {root }, 0}\right)$ times a function of root (soil) temperature (mean 0- to 20-cm-soil temperature) and root nitrogen content [Ryan, 1991], calculated as root carbon content $\left(C_{\text {root }}, \mathrm{mol} \mathrm{m}^{-2}\right)$ times the root $\mathrm{C}: \mathrm{N}$ ratio,

$$
R_{\text {root }}=\frac{R_{\text {root }, 0} C_{\text {root }}}{(C: N)_{\text {root }}} \cdot Q_{10, r}^{\left(\frac{T_{\text {root }}}{10}\right)},
$$

with a $Q_{10, r}$ value of 1.8 [Ryan, 1991]. Root carbon was a dynamic variable in the model (see section 2.1.3). Woody tissue respiration was calculated as a base rate $\left(R_{\text {wood, } 0}\right)$ 


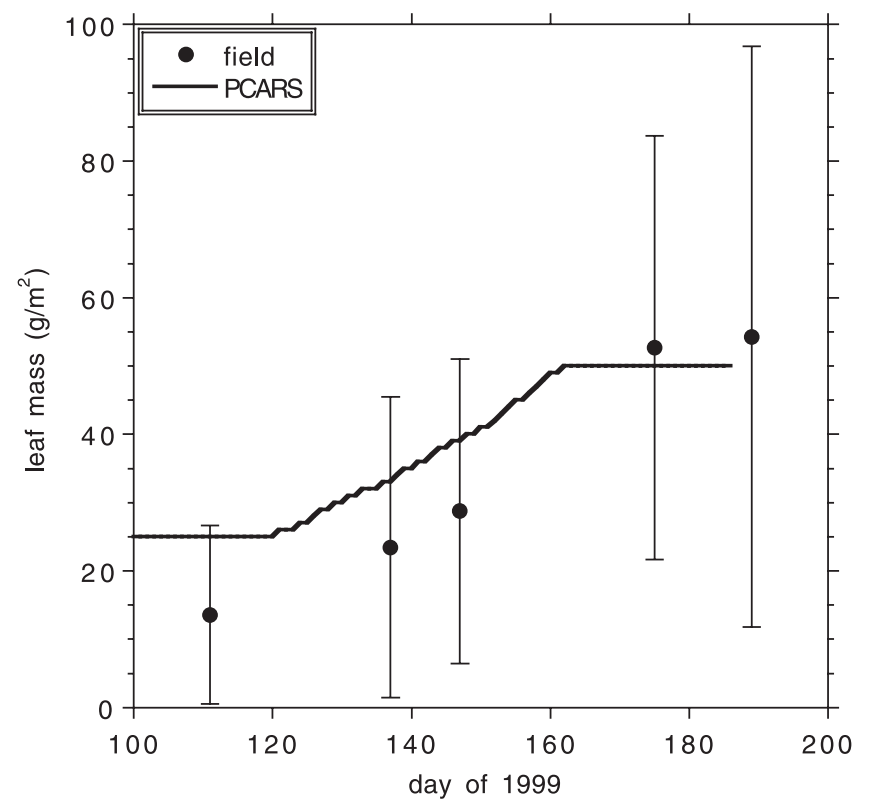

Figure 2. Evergreen shrub leaf phenology measured at Sallie's Fen in New Hampshire. Each point represents mean and standard deviation of 15 observations of leaf mass in spring of 1999 (see text for details). Line represents PCARS spring leaf phenology for evergreen shrubs, where winter leaf biomass is half maximum (i.e., 2-year leaf retention) and leaf growth in spring is linear with accumulating positive degree days, starting at $200^{\circ} \mathrm{C}$ days and finishing at $800^{\circ} \mathrm{C}$ days.

times a function of sapwood volume per unit ground area, $S_{v}$, and air temperature, $T_{\text {air, }}$ [Ryan et al., 1995],

$$
R_{\text {wood }}=R_{\text {wood }, 0} S_{v} Q_{10, s}^{\left(\frac{T_{\text {air }}-10}{10}\right)},
$$

with a $Q_{10, s}$ value of 1.7 [Ryan et al., 1995]. Sapwood volume was a site-specific input parameter and was considered constant throughout each simulation. The minimum temperature for all plant respiration was $0^{\circ} \mathrm{C}$.

\subsubsection{Phenology, dormancy, and carbon allocation}

[15] PCARS simulates the dynamics of vascular plant leafiness with a simple degree-day function. Each vegetation type has a prescribed minimum and maximum leaf biomass. In the spring, vascular plant leaf biomass increases from minimum to maximum as a function of accumulating heat sum as positive degree days. In the fall, senescence and leaf drop (to minimum leaf biomass) occurs on a single day, after an accumulation of -25 chilling degree days (sum of daily average temperatures below $0^{\circ} \mathrm{C}$, after 1 July).

[16] There has been little information published on the phenology of peatland vegetation. We collected a simple data set to develop an initial model. At Sallie's Fen (a poor fen in southeastern New Hampshire described by Frolking and Crill [1994]), leaf number and leaf length were measured on single branches of three evergreen shrubs at irregular intervals during the spring and summer of 1999; leaf amount was the product of average leaf length and number of leaves. Air temperature was measured continuously until late June by standard micrometeorological methods. Positive degree days were calculated as the accumulating sum of all daily mean air temperatures $>0^{\circ} \mathrm{C}$. The vegetation phenology for spring leaf flush (Figure 2) was modeled as a linear increase in leaf biomass from the minimum (winter) biomass to the maximum as the accumulated positive degree days rose from $200^{\circ}$ to $800^{\circ} \mathrm{C}$ days.

[17] The minimum photosynthetic rate for evergreen vascular vegetation was set to $5 \%$ of the growing season $P_{\text {max }}$. As evergreen vascular plants emerged from winter dormancy [Villiers, 1975] the maximum potential photosynthetic rate increased linearly from 5 to $100 \%$ of $P_{\max }$ (Table 1) as the positive degree days rose from $0^{\circ}$ to $200^{\circ} \mathrm{C}$ days, at which point new leaves began to emerge. Frosts in the fall caused partial dormancy [Hadley, 2000], with the maximum potential photosynthetic rate dropping by $30 \%$ each time that the minimum daily air temperature was less than $-2^{\circ} \mathrm{C}$. Mosses were not affected by either of these dormancy factors, and their metabolic rate on any day was given directly by equation (1).

[18] Carbon allocation occurred on a daily time step. Each day, NPP was calculated as the sum of hourly photosynthesis, foliar respiration, root respiration (vascular plants only), and spwood respiration (trees and shrubs only). For mosses, daily NPP (positive or negative) was added to an accumulating carbon pool that, on the day of vascular plant leaf drop, was added to the aboveground litter pool. For vascular plants, carbon for leaf development came from the root carbon pool, and daily NPP was stored in the root carbon pool. The root carbon pool had a prescribed minimum value. If a day's leaf production (Figure 2) could not be met by available root carbon, production was reduced to the available root carbon. This deficit would be made up on subsequent days, if possible, but could result in leaf biomass below maximum in or following a year of poor NPP. If a vegetation type had negative NPP (total respiration greater than total photosynthesis) over a complete day that could not be met by available root carbon, all rates were reduced to match the available root carbon. As a result, the root carbon mass declined in spring as leaves developed, increased over the summer when NPP was generally positive, and declined slowly in the fall and winter due to low cold-season respiration rates.

[19] A portion of live roots were converted to litter on the same day as foliar litterfall. On that day the root mass was reduced to the maximum foliar biomass divided by the aboveground/belowground mass ratio (Table 2), and the root litter was distributed as fresh tissue to each of the litter/ peat layers (see section 2.2) in the rooting zone. Root litter

Table 2. Mer Bleue Bog Site-Specific PCARS Parameters

\begin{tabular}{lccl}
\hline \multicolumn{1}{c}{ Parameter } & Value & Units & \multicolumn{1}{c}{ Reference } \\
\hline Shrub foliar mass range & $45-90$ & $\mathrm{~g} \mathrm{C} \mathrm{m}^{-2}$ & Moore et al. [2002] \\
Shrub sapwood volume & 0.003 & $\mathrm{~m}^{3} \mathrm{~m}^{-2}$ & Moore et al. [2002] \\
Shrub specific leaf area & 0.006 & $\mathrm{~m}^{2} \mathrm{~g}^{-1}$ & Small [1972] \\
Shrub root depth & 0.3 & $\mathrm{~m}$ & Moore et al. [2002] \\
$\begin{array}{l}\text { Shrub aboveground/ } \\
\text { belowground mass ratio }\end{array}$ & 0.666 & - & Moore et al. [2002] \\
Moss capitulum mass & 75 & $\mathrm{~g} \mathrm{C} \mathrm{m}^{-2}$ & Moore et al. [2002] \\
\hline
\end{tabular}


Table 3. Mer Bleue Bog Peat Profile Initialization Parameter Values

\begin{tabular}{lcl}
\hline Parameter & Value & \multicolumn{1}{c}{ Comments } \\
\hline$Z_{\mathrm{WT}}$ & 0.3 & long-term mean water table depth (m) [Frolking et al., 2001] \\
$Z_{\text {anox }}$ & 0.05 & thickness of oxic/anoxic transition (m) [Frolking et al., 2001] \\
$\rho_{\text {surf }}$ & 0.055 & surface peat bulk density $\left(\mathrm{g} \mathrm{cm}^{-3}\right)$ (P.J.H. Richard, unpublished data, 2000) \\
$\rho_{\text {deep }}$ & 0.090 & deep peat bulk density $\left(\mathrm{g} \mathrm{cm}^{-3}\right)$ (P.J.H. Richard, unpublished data, 2000) \\
Age & 8500 & peat basal age (years) (P.J.H. Richard, unpublished data) \\
Moss NPP & 75 & assumed value for long-term mean value $\left(\mathrm{g} \mathrm{C} \mathrm{m}^{-2} \mathrm{yr}^{-1}\right)$ \\
Shrub NPP $^{\mathrm{a}}$ & 100 & Assumed value for long-term mean value $\left(\mathrm{g} \mathrm{C} \mathrm{m}^{-2} \mathrm{y}^{-1}\right)$ \\
\hline
\end{tabular}

${ }^{\mathrm{a}}$ Net primary productivity.

inputs were assumed to be uniform with depth, so additions were largest for the thickest layers. Layer thickness was a function of layer mass and peat bulk density, $\rho(z)$, which increases with depth, $z$, in meters, as

$$
\rho(z)=\rho(0)+\frac{\Delta \rho}{1+\Delta \rho \exp (-20 z)},
$$

where $\rho(0)$ is the surface bulk density, $\rho(0)+\Delta \rho$ is the bulk density at the bottom of the peat (Table 3 ).

\subsection{Decomposition}

[20] The entire peat profile decomposes rapidly in the aerobic surface zone and slowly in the anaerobic deep peat. For this reason, the PCARS model needs to have the entire peat profile initialized (mass and decomposability). This is done via a decomposition and peat accumulation model that has been described elsewhere [Frolking et al., 2001] and is summarized briefly here. Because the same decomposition formulation is used for both the peat profile initialization (an $~ 8000$-year process) and the calculation of current instantaneous decomposition rates in PCARS, the contemporary fluxes in the model are inherently consistent with the long-term peat accumulation dynamics. This is an important feature for a process-oriented model, but it also constrains model behavior (see sections 4.6 and 5).

[21] The basic premise is that litter/peat can be modeled as a collection of vertically stratified layers of increasing age down the peat profile. Each layer started at the surface with an initial mass (aboveground litterfall). Layer decomposition was modeled as a first-order process, with the decomposability, $k$, declining linearly with mass loss as

$$
k=k_{0} \frac{m}{m_{0}}
$$

where $k_{0}$ is the initial tissue decomposability, $m_{0}$ is the initial litter mass input, and $m$ is the decomposing tissue mass remaining at some later time. In each year of a simulation a new layer is added to the surface of the litter/ peat, and other layers are buried progressively deeper in the profile. Until they are buried below the root zone, layers receive an input of fresh root litter, $m_{\text {root }}$, each year. This increases both the layer mass and its decomposability (adding $m_{\text {root }}$ to both the numerator and denominator of equation (8)). Since each plant type can have different litter production rates and different tissue decomposability, each litter type was tracked separately within an annual layer. The mass loss of a tissue type $i$ in a layer $j$ was modeled as

$$
\frac{d m_{i, j}}{d t}=-k_{i, j} m_{i, j} f_{d}\left(T_{j}\right) f_{d}\left(W_{j}\right),
$$

where $k_{i, j}$ is the decomposability of tissue type $i$ in layer $j$ (as calculated with equation (8) (see Frolking et al. [2001] for details), $m_{i, j}$ is the remaining mass of tissue type $i$ in layer $j$, and $f_{d}\left(T_{j}\right)$ is a temperature effect multiplier for decomposition and $f_{d}\left(W_{j}\right)$ is a moisture effect multiplier for decomposition for layer $j$. The litter/peat profile was initialized assuming constant vegetation composition and productivity and constant mean annual peat temperature and water table for several millennia [Frolking et al. 2001].

[22] The temperature modifier was a simple exponential function $\left(Q_{10, d}=2\right)$ for positive temperatures and fell to zero when soil temperature dropped below $T_{\min }$ as

$$
\begin{array}{lll}
f_{d}\left(T_{i}\right)=0 & T_{i}<T_{\min }, \\
f_{d}\left(T_{i}\right)=\left(\frac{T_{i}-T_{\min }}{\left|T_{\min }\right|}\right)^{0.5} & & T_{\min }<T_{i}<0^{\circ} \mathrm{C}, \\
f_{d}\left(T_{i}\right)=Q_{10, d}^{T i / 10} & T_{i}>0^{\circ} \mathrm{C} .
\end{array}
$$

$T_{\min }$ was set to $-4^{\circ} \mathrm{C}$ for heterotrophic metabolism [Clein and Schimel, 1995]. The moisture modifier, $f_{d}\left(W_{i}\right)$, was set to 1.0 at peat water-filled pore space of layer $i\left(W_{i}\right)$ of 0.6 [Linn and Doran, 1984], declined linearly to zero as peat dessicated, and fell to a low, nonzero rate, $f_{\text {anox }}$, as peat saturated. The deep peat anaerobic decomposition rate $f_{\text {anox }}$, was reached either at the bottom of the root zone, if the roots penetrated below the water table, or $0.05 \mathrm{~m}$ below the water table and persisted to the bottom of the peat profile. If $z^{*}$ is the deeper of these two depths $\left(z_{\text {root }}\right.$ and $\left.z_{\mathrm{WT}}+0.05\right)$, then

$$
\begin{array}{cc}
f_{\text {anox }}^{*}=f_{\text {anox }}+\left(\frac{1-f_{\text {anox }}}{2}\right)\left(\frac{z^{*}-z}{z^{*}-z_{\mathrm{WT}}}\right) z_{W T}<z<z^{*} \\
f_{\text {anox }}^{*}=f_{\text {anox }} & z>z^{*},
\end{array}
$$

and the decomposition multiplier for water content was given by

$$
\begin{aligned}
& f_{d}\left(W_{i}\right)=1-\left(\frac{0.6-W_{i}}{0.6}\right)^{5} \quad W_{i}<0.6 \\
& f_{d}\left(W_{i}\right)=1-\left(1-f_{\text {anox }}^{*}\right)\left(\frac{W_{i}-0.6}{1.0-0.6}\right)^{3} \quad W_{i} \geq 0.6 .
\end{aligned}
$$


The $f_{\text {anox }}$ was set to 0.025 (bog value from Frolking et al. [2001]). The product of the three effects that reduce decomposition rates (temperature, waterlogging, and increasing tissue recalcitrance with mass loss) decreased decomposition rates by about a factor of 1000 from the top to the bottom of the peat profile [Frolking et al. 2001].

[23] Peat decomposition in PCARS represents carbon loss by peat tissue, so it is assumed to generate $\mathrm{DOC}, \mathrm{CO}_{2}$, and $\mathrm{CH}_{4}$. PCARS does not explicitly simulate DOC production and decay. DOC export from the peatland was calculated as an empirical function of water runoff (see section 2.4), and this was subtracted from the decomposition mass loss (equation (9)) integrated down the peat profile); the remaining decomposition was partitioned into $\mathrm{CO}_{2}$ and $\mathrm{CH}_{4}$. Methane was generated by anaerobic decomposition below the water table (see section 2.3). All $\mathrm{CO}_{2}$ production (and methane oxidized to $\mathrm{CO}_{2}$ ) was assumed to be immediately released to the atmosphere.

\subsection{Methane Production, Oxidation, and Flux}

[24] Methane production occurs under anoxic conditions, i.e., below the water table in peatlands [Conrad, 1989]. Methane transport to the atmosphere occurs via three pathways: diffusion, ebullition (bubbling), and plant-mediated transport [Conrad, 1989]. For both diffusive and plant-mediated transport, some fraction of the methane can be oxidized to $\mathrm{CO}_{2}$ before reaching the atmosphere.

[25] In PCARS, when organic matter decomposes under anoxic conditions, $\mathrm{CO}_{2}$ and $\mathrm{CH}_{4}$ are generated in equal proportions [Conrad, 1989]. All $\mathrm{CH}_{4}$ generated from decomposition goes into a single dissolved-methane pool, with a volume equal to the total water content of the peat below the water table. The model does not simulate a gradient in dissolved methane. Methane escapes from the dissolved phase by two mechanisms: rapid flux (i.e., bubbles and a fraction of plant-mediated transport), which cannot be oxidized before reaching the atmosphere, and slow flux (i.e., diffusive and the remaining fraction of plantmediated transport), which can be oxidized before reaching the atmosphere.

\subsubsection{Rapid flux}

[26] There is no explicit treatment of bubbles in PCARS. If the methane concentration exceeds a threshold concentration, all dissolved methane above this threshold concentration is assumed to be lost by rapid flux in that daily time step. In the absence of plant-mediated transport (i.e., no sedge roots) the threshold concentration is set at $1 \mathrm{mmol}$ [Rothfuss and Conrad, 1994]. This algorithm cannot simulate large fluxes associated with supersaturation and episodic bubble losses, but, over a season, will emit, at a slow rate and via an oxidation-free pathway, all methane that would lead to supersaturation and be emitted via ebullition.

\subsubsection{Diffusive flux and diffusive path length}

[27] In PCARS the limiting factor in diffusive flux is the diffusion of dissolved methane in peat water to the watergas interface, while the gas-phase diffusion is assumed to be essentially instantaneous (though the methane can be oxidized during that instant). Since the model does not simulate a dissolved methane concentration profile, diffusive flux in the pore water was calculated by assuming that as the dissolved $\mathrm{CH}_{4}$ molecules make their random walks through the solution, any that reach the air-water interface are transferred to the gas phase, because of a large concentration gradient there. The root-mean-square path length for a $\mathrm{CH}_{4}$ molecule dissolved in water, $z_{\mathrm{rms}}$, can be calculated on the basis of a random walk approach [Denny, 1993] as

$$
z_{\mathrm{rms}}=\sqrt{2 D t},
$$

where $D$ is the diffusivity of methane in water $(\sim 1.5 \times$ $10^{-9} \mathrm{~m}^{2} \mathrm{~s}^{-1}$ [Denny, 1993]), and $t$ is the time period (1 day $=86,400 \mathrm{~s}$ ), so $z_{\mathrm{rms}}=0.016 \mathrm{~m}$. After 1 day the vertical distribution of methane molecules that start the day at an arbitrary depth will be a normal distribution around that depth with a standard deviation equal to $z_{\text {rms }}$ [Denny, 1993]. Any portion of this distribution that is above the water table is assumed to have been transferred from solution to the pore gas phase, where it is transported to the atmosphere or oxidized. Thus the fraction of methane lost by diffusion to the surface as a function of depth below the surface is the same as the one-sided probability, given a normal distribution, of a value greater than that depth; that is

$$
f(z)=\int_{z}^{\infty} \frac{d z}{z_{\mathrm{rms}} \sqrt{2 \pi}} \exp \left(-\mathrm{z}^{2 /\left(\mathrm{z}_{\mathrm{ms}}^{2}\right)} .\right.
$$

[28] The net diffusive flux is then the integral of this fractional loss down the profile to the base of the peat, $z_{\max }$, times the dissolved methane concentration,

$$
\begin{aligned}
F= & {\left[\mathrm{CH}_{4}\right] \int_{0}^{z_{\max }} f(z) d z=\left[C H_{4}\right] \int_{0}^{z_{\max }} d z \int_{0}^{\infty} \frac{d z^{\prime}}{z_{\mathrm{rms}} \sqrt{2 \pi}} } \\
& \cdot \exp \left(-z^{\prime 2} /\left(2 z_{\mathrm{rms}}^{2}\right) .\right.
\end{aligned}
$$

[29] Since by $1 \mathrm{~m}$ depth the fraction lost is effectively zero (by $0.1 \mathrm{~m}$, the fraction lost is close to zero), we can extend the integral to infinite depth and approximate the solution as

$$
\begin{aligned}
F & =\left[\mathrm{CH}_{4}\right] \int_{0}^{z_{\max }} f(z) d z \\
& \approx\left[\mathrm{CH}_{4}\right] \int_{0}^{\infty}\left(\int_{z}^{\infty} \frac{\exp \left(-z^{\prime^{2}} /\left(2 z_{\mathrm{rms}}^{2}\right)\right.}{z_{\mathrm{rms}} \sqrt{2 \pi}} d z^{\prime}\right) d z \\
& \approx\left[\mathrm{CH}_{4}\right]\left(1-\exp (-1) \frac{\sqrt{2 \pi}}{4} z_{\mathrm{rms}}\right. \\
& \approx 0.4\left[\mathrm{CH}_{4}\right] z_{\mathrm{rms}} .
\end{aligned}
$$




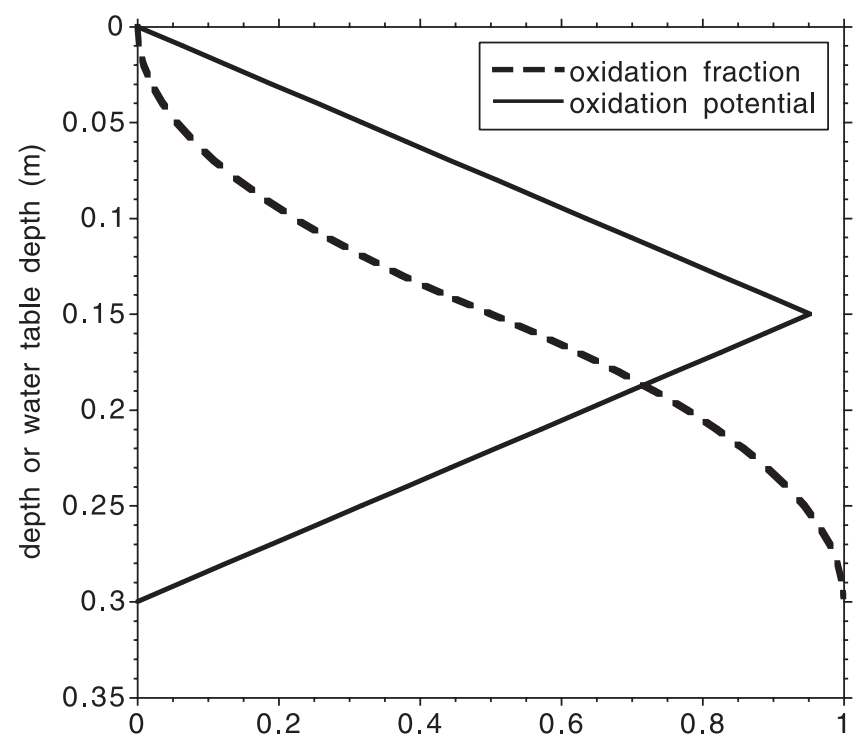

Figure 3. Methane oxidation potential profile (solid line) as a function of depth in peat profile. Fraction of diffusive flux methane oxidized is equal to area under triangular curve integrated from water table depth to surface; this is given, as a function of water table depth, by the dashed line. In this case, if water table depth is $>0.3 \mathrm{~m}$, all diffusive flux methane is oxidized. Profile is for Mer Bleue; other peatlands might have different oxidation potential curves or depths.

[30] Taking $\left[\mathrm{CH}_{4}\right]$ at $1.0 \mathrm{mmol}$, this gives a diffusive flux (before oxidation) of $\sim 100 \mathrm{mg} \mathrm{CH}_{4} \mathrm{~m}^{-2} \mathrm{~d}^{-1}$. Diffusive loss would be $\sim 0.4 \%$ of the dissolved methane pool size per day (for $\sim 2 \mathrm{~m}$ of peat), so degassing by this mechanism would take months.

\subsubsection{Methane oxidation}

[31] Following the approach of Granberg et al. [1997], there is a methane oxidation potential related to the population distribution of methane oxidizers. This is likely to be an approximately normal distribution centered somewhat above some mean (or most frequent) water table depth. To simplify the problem, the distribution can be made triangular (Figure 3). Then the fraction of diffusively emitted methane that is oxidized will be equal to the area under the oxidation potential curve between the water table depth and the peat surface, where the oxidation potential curve is normalized to have a total area of 1.0 (Figure 3). This is similar to the formulation of Potter [1997] with fractional methane oxidation a function of water table depth.

\subsubsection{Effect of plants}

[32] Only certain plants (e.g., sedges, especially Carex spp.) can directly transport methane to the atmosphere through their arenchyma. At Mer Bleue, sedges are not abundant, and any effect of these plants was considered to be insignificant.

\subsection{DOC Losses}

[33] A simple, empirical model of DOC loss was developed from data collected at Mer Bleue Bog [Fraser et al.,
2001]. DOC concentration ([DOC], $\mathrm{mg} \mathrm{C} \mathrm{L}^{-1}$ ) was empirically related to runoff, $R$ in $\mathrm{mm} \mathrm{d}^{-1}$, as

$$
[\mathrm{DOC}]=47-6.1 R \text {. }
$$

[34] Runoff was an input variable to the model. DOC loss was then calculated as the product of hourly runoff, $R$, and [DOC]. As equation (17) was developed with data from Mer Bleue [Fraser et al., 2001, Figures 3 and 4], it was not independently evaluated and served only to conserve carbon in a complete carbon balance. Different parameters would likely be required for model application to other sites.

\section{Site and Data Sets}

[35] We compared PCARS simulations to field data collected at Mer Bleue Bog, a large, raised ombrotrophic bog $15 \mathrm{~km}$ east of Ottawa, Ontario $\left(45^{\circ} 25^{\prime} \mathrm{N}, 75^{\circ} 40^{\prime} \mathrm{W}\right.$; elevation $65 \mathrm{~m}$; surface area $\sim 28 \mathrm{~km}^{2}$ ). The mean peat depth is $\sim 4 \mathrm{~m}$, and it is underlain by lacustrine sediments and marine clay from the westernmost end of postglacial Champlain Sea [Mott and Camfield, 1969]. The bog has a complete ground cover of mosses (Sphagnum capillifolium,S. magellanicum), with a shrub canopy dominated by evergreen shrubs (Chamaedaphne calyculata, Kalmia angustifolia, and Ledum groenlandicum), with some deciduous shrubs (Vaccinium myrtilloides) and scattered sedges (e.g., Eriophorumvaginatum); discontinuous patches of black spruce (Picea mariana) and larch (Larix laricina) occur in the central part of the peatland [Joyal, 1970]. The climate is cool-temperate with a mean annual temperature of $5.8^{\circ} \mathrm{C}$ and a mean annual precipitation of $910 \mathrm{~mm}$ [Environment Canada, 1993].

\subsection{Data Required to Run Model}

[36] To simulate the carbon balance of a particular peatland, PCARS requires site-specific data in three categories. First, the model requires data for initializing the peat profile, following the method outlined by Frolking et al. [2001]. This algorithm requires values for the basal date of the peat, peat bulk density, long-term mean vegetation NPP for each plant type, rooting depth for each plant type, and initial tissue decomposition rate for each plant type. Since Mer Bleue is dominated by ericaceous shrubs and Sphagnum mosses, we included only these two vegetation types (Tables 1 and 2). The second required data set is a site-specific description of the vegetation: maximum and minimum foliar biomass, tissue photosynthetic rate, aboveground/belowground biomass ratios for the vascular plants, DOC concentrations in water seeping from the peatland, and a depth range for methane oxidation (Tables 1 and 2). The third site-specific data set required is hourly (or daily) weather data to drive the simulations: air and soil temperatures, water table depth, incoming PAR, relative humidity, and water runoff. In the model evaluation below, we used data obtained from measurements at Mer Bleue (Figure 4) [Lafleur et al., 2001], but the model was designed such that it can also to be driven directly by output from CLASS, the land surface component of the Canadian Climate Model [Verseghy, 2000], and this will be done in future analyses. Alterna- 

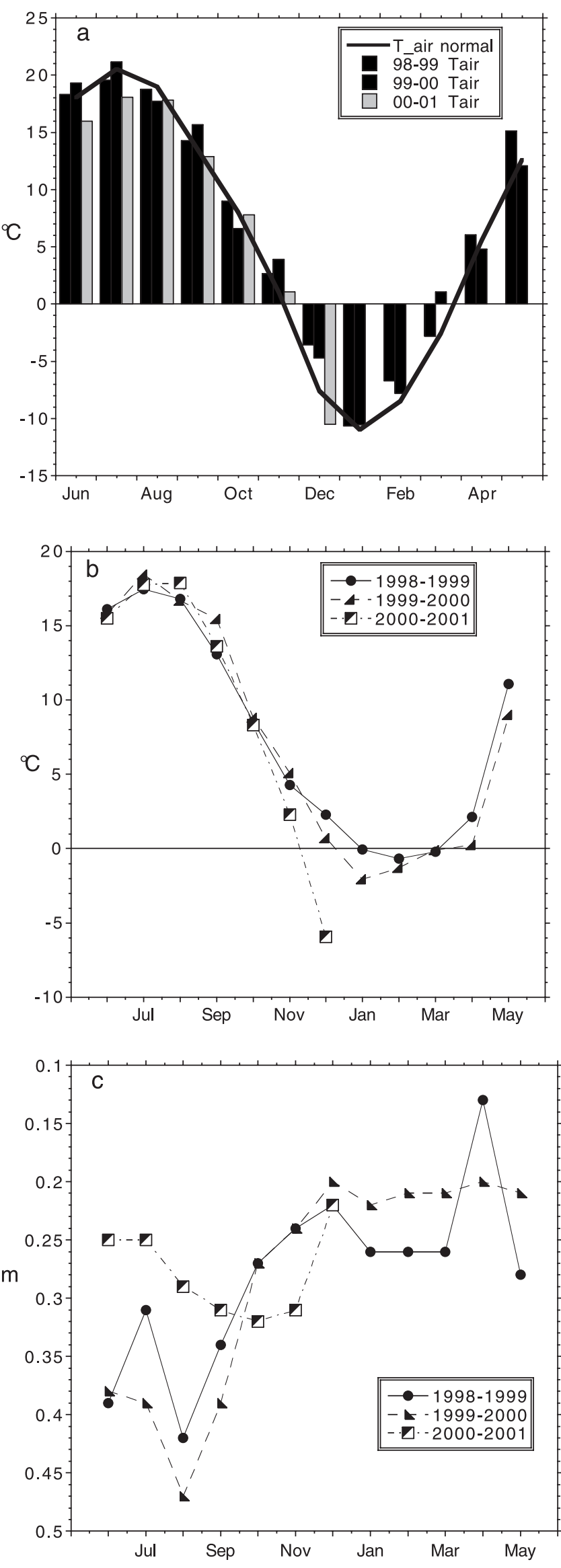

tively, station weather data could be used to drive a peat soil climate model [e.g., Granberg et al., 1999; Frolking and Crill, 1994] to generate peat temperatures and water table depth. An additional set of model parameters, based on literature values, are not site specific, and are expected to be constant across simulations of a range of northern peatlands (Table 1).

[37] Soil temperatures for each layer of the peat profile were calculated by linearly interpolating between depths provided by the input data (the midpoint of each layer in Table 4). Soil moisture content in layers in the unsaturated zone above the water table was calculated using water retention curves parameterized for peatlands by Letts et al. [2000]. Since peat soil has extremely high porosity, we made a reasonable simplifying assumption that the water in peat soils is always in equilibrium between gravitational and matric tension (as in the work by Frolking and Crill, [1994]). Then soil water tension for an unsaturated layer is equal to distance above the water table, $z_{\mathrm{WT}}-z_{i}$, and soil water content (as water-filled pore space) in the unsaturated zone is given by

$$
\begin{aligned}
& W_{i}=\left(\frac{z_{\mathrm{WT}}-z_{i}}{\psi_{\mathrm{sat}}}\right)^{-1 / b} \quad\left(z_{\mathrm{WT}}-z_{i}\right)>\psi_{\mathrm{sat}} \\
& W_{i}=1.0 \quad\left(z_{\mathrm{WT}}-z_{i}\right) \leq \psi_{\mathrm{sat}},
\end{aligned}
$$

where $\psi_{\text {sat }}$ is the air-entry matric tension and $b$ is parameter specific to the peat type (fibric, relatively undecomposed; hemic, partially decomposed; or sapric, highly decomposed [Letts et al., 2000]); parameter values are listed in Table 4.

[38] Moss photosynthesis and respiration rates vary with moss water content [Titus and Wagner, 1984; Silvola, 1990; Williams and Flannagan, 1996]. Moss water content (g water/g moss biomass) was modeled as a linear function of water table depth in meters as

$$
W_{\text {moss }}=8.8-12.5 z_{\mathrm{WT}}
$$

based on observations at Mer Bleue during the summer of 1999 (Stuart Admiral, Trent University, unpublished data, 1999). In addition, mosses wet up during even light rains, and moss productivity can be very dependent on frequency of rains [Busby et al., 1978; Frolking, 1997]. We estimated a moss interception capacity at $8 \mathrm{~mm}$ [Price et al., 1997], and each rain greater than $8 \mathrm{~mm}$ wet the moss to capacity. The moss subsequently dried by evaporation, modeled as an exponential decay in the intercepted water pool, $W_{\text {int }}$, [Frolking et al., 1996] as

$$
W_{\text {int }}(t+1)=\left(1-k_{\text {int }}\right) W_{\text {int }}(t),
$$

where $k_{\text {int }}$ is the loss rate per time step ( $1 \%$ per hour).

[39] The actual surface to which the water table is referenced in a peatland is a difficult term to quantify

Figure 4. (opposite) (a) Monthly air temperature, (b) monthly soil temperature, and (c) monthly mean water table depth for June 1998 through May 1999 (year 1); June 1999 through May 2000 (year 2) and June 2000 through December, 2000 (year 3) for Mer Bleue Bog, near Ottawa, Ontario, Canada. 
Table 4. Mer Bleue Bog Peat Hydraulic Parameters Values

\begin{tabular}{cccl}
\hline Peat layer & Depth Range, $\mathrm{m}$ & $b^{1}$ & $\psi_{\text {sat }}, \mathrm{m}^{\mathrm{a}}$ \\
\hline 1 & $0.0-0.25$ & 3 & 0.001 \\
2 & $0.25-0.35$ & 4 & 0.01 \\
3 & 0.35 -bottom & 16 & 0.01 \\
\hline
\end{tabular}

${ }^{\mathrm{a}}$ Water-filled pore space content calculated as $W=\left(Z / \psi_{\text {sat }}\right)^{-1 / b}$, where $Z$ is distance above water table [Letts et al., 2000].

because of the microtopography produced by hummocks and hollows. We dealt with this issue by referencing our water table to an average surface assuming that hummocks and hollows occupied 0.7 and 0.3 of the peatland, respectively, and that the average difference in height was $0.25 \mathrm{~m}$ [Remier, 2001]. Growing season manual chamber $\mathrm{CO}_{2}$ flux results from Mer Bleue show that hummocks and hollows are not significantly different in their NEE, gross photosynthesis, and total respiration, when compared within climatically similar growing seasons, but hollows had larger differences in respiration between wet and dry summers than did hummocks (i.e., they had a slightly stronger response to a lower water table) (J.L. Bubier et al., Between year and site variability in growing season net ecosystem $\mathrm{CO}_{2}$ exchange at a large peatland, Ontario, Canada, submitted to Ecosystems, 2002). While it would be possible to run the model for both hummock and hollow, several complications arise. For example, how much of the shrub vegetation occupies the hummock ground and how much occupies the hollow? The shrub stems are quite a tangle and this would be difficult to quantify. It would get even worse when one had to estimate what fraction of a hummockdwelling shrub's roots extended into the hollow peat and thus decompose there, or how many of its leaves fell onto the hollow peat. Finally, our long-term view is regional application within the framework of CLASS and the Canadian GCM, and at that scale, hummock/hollow resolution and differentiation may not be important.

\subsection{Data for Model Evaluation}

[40] An eddy covariance tower has been operating nearly continuously at the Mer Bleue Bog since June 1998. The instrumentation and an analysis of the first full year of data have been described by Lafleur et al. [2001]. For this paper we used the first 2 years of flux data (1 June 1998 through 31 May 2000); below, year 1 refers to 1 June 1998 through 31 May 1999, and year 2 refers to 1 June 1999 through 31 May 2000. Gap filling in the Mer Bleue tower flux data has been outlined by Lafleur et al. [2001]. Briefly, short gaps (up to a few hours) were filled by linear interpolation. During periods with no snow cover, longer gaps during the daytime were filled with an empirical NEE-PAR relationship: Separate NEE-PAR curves were fit for each month, using a rectangular hyperbola function, as given by Frolking et al. [1998]. Nighttime data gaps were filled with an empirical $\mathrm{NEE}_{\text {night }}-T_{\text {soil }}$ relationship: Separate NEE curves were fit for each year, based on May-October data, using all available data. During periods of snow cover, data gaps were filled with average fluxes for the 10-day period surrounding the missing data. Total ecosystem respiration (day or night) was calculated with these same $\mathrm{NEE}_{\text {night }}-T_{\text {soil }}$ relationships. Gross photosynthesis was estimated as the NEE minus total ecosystem respiration. All flux data and model-simulated fluxes have been aggregated to daily totals and 5-day means for comparison. As there was model driver data available for June-December 2000, we ran a full 3year PCARS simulation (1998-2000), using January-May 1999 driver data also for the January-May 1998 part of the simulation. Most results are compared to measurements over the June 1998 through May 2000 period, but some model results are reported below for the three calendar years.

\section{Results}

\subsection{Initialization of Peat Profile}

[41] The initial peat profile resembles dated peat cores over the top $3 \mathrm{~m}$ or past 6000 years of accumulation, but has significantly less peat remaining from the first few millennia of Mer Bleue's development (Figure 5). The total simulated profile contains $144 \mathrm{~kg} \mathrm{C} \mathrm{m}^{-2}$ of peat, compared with 0.28 $\mathrm{kg} \mathrm{C} \mathrm{m}{ }^{-2}$ of live vegetation. These results are discussed in greater detail by Frolking et al. [2001].

\subsection{Net Ecosystem Exchange of $\mathrm{CO}_{2}$}

[42] Daily NEE at Mer Bleue has a strong seasonal cycle, with variable net ecosystem uptake of +2 to $-2 \mathrm{~g} \mathrm{C} \mathrm{m}^{-2} \mathrm{~d}^{-1}$ during the growing season (May through September) and

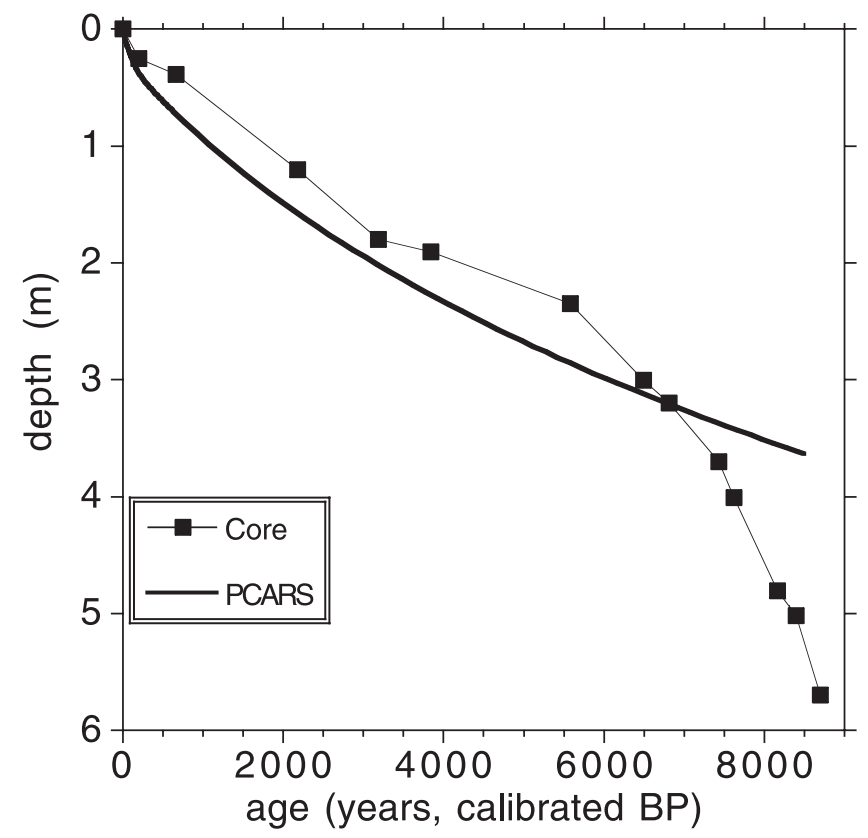

Figure 5. Age-depth profile for peat at Mer Bleue Bog in vicinity of eddy covariance tower and as simulated by PCARS. Solid line is PCARS peat profile initiation, and points are ${ }^{14} \mathrm{C}$ ages (see Frolking et al. [2001] for details). Model thus has a 3.6-m peat profile, with $\sim 8500$ annual peat layers; each layer has an initial mass and decomposability (see equation (8)). PCARS uses these to calculate instantaneous decomposition of each layer and then aggregates profile to calculate total decomposition, one component of site carbon balance. 

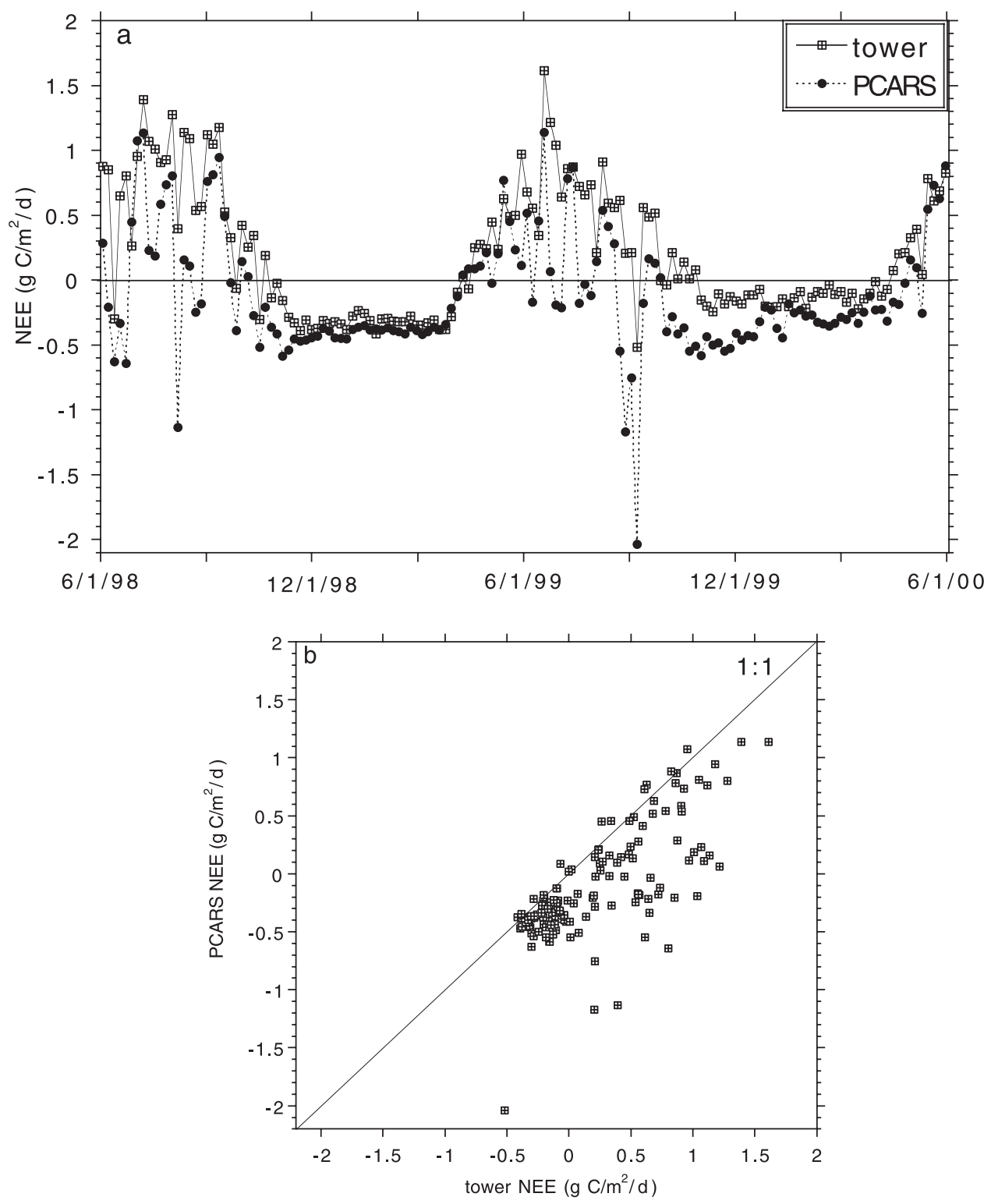

Figure 6. (a) Time series of 5-day average net ecosystem exchange (NEE) fluxes as measured by tower and as simulated by PCARS. (b) Scatterplot of tower and PCARS NEE fluxes, with 1:1 line. PCARS NEE was biased toward ecosystem respiration (carbon loss) relative to the tower. Sign convention is that net carbon uptake by peatland is a positive NEE.

relatively steady net ecosystem loss of 0 to $-0.5 \mathrm{~g} \mathrm{C} \mathrm{m}^{-2}$ $\mathrm{d}^{-1}$ during the winter (December through April). (The sign convention in this paper is that net carbon uptake by the peatland is represented by positive NEE.) The onset of net daily carbon uptake began in late April/early May each year. Compared to tower NEE, simulated NEE was biased toward net ecosystem respiration (i.e., carbon loss), particularly during low-productivity days in the growing season and during the second winter season (1999-2000). As model and tower fluxes were averaged over longer intervals (1 day to 1 month), the coefficient of determination $\left(r^{2}\right)$ increased from $\sim 0.5$ to $\sim 0.65$, all significant to $\mathrm{p}<0.01$. This increase in correlation, despite a decrease in sample size, reflects the stronger correlation for seasonal variability in fluxes, which dominates a monthly averaging, than for daily variability. All subsequent comparisons of $\mathrm{CO}_{2}$ fluxes (modeled versus measured) are based on 5-day averages, as they are easier to visually interpret.

[43] Model bias toward respiration is clear in the 5-day mean NEE time series plot (Figure 6a), in a scatterplot (Figure 6b), and as the discrepancy (tower flux minus PCARS flux, Figure 7a), which had a mean of $\sim 0.32 \mathrm{~g}$ $\mathrm{C} \mathrm{m}^{-2} \mathrm{~d}^{-1}$ and a range of -0.2 to $1.5 \mathrm{~g} \mathrm{C} \mathrm{m}^{-2} \mathrm{~d}^{-1}$. We also calculated first differences of the 5-day mean NEE fluxes as a 5-day mean value minus the mean value for the previous 5-day interval. This represents the ecosystem flux response to changes in weather patterns on this timescale, which is roughly the scale of weather front passage in this 

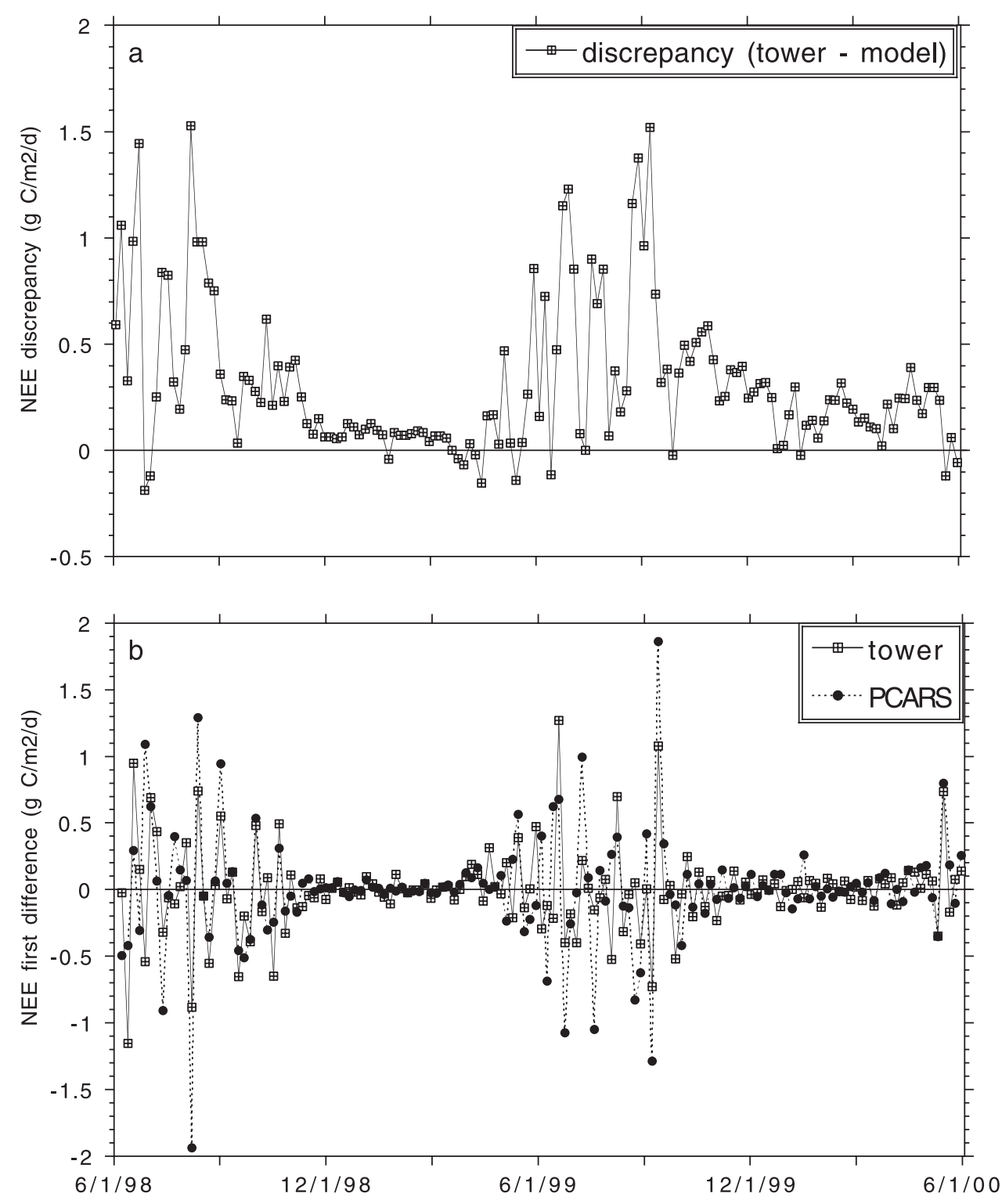

Figure 7. (a) Time series of discrepancy between measured and modeled NEE (tower flux minus PCARS flux). Mean growing season discrepancy was $\sim 0.5 \mathrm{~g} \mathrm{C} \mathrm{m}^{-2} \mathrm{~d}^{-1}$, while winter discrepancy was $\sim 0.1 \mathrm{~g} \mathrm{C} \mathrm{m}^{-2} \mathrm{~d}^{-1}$ during 1998-1999 winter and was $\sim 0.25 \mathrm{~g} \mathrm{C} \mathrm{m}^{-2} \mathrm{~d}^{-1}$ during 1999-2000 winter. (b) Time series of first differences of 5-day mean NEE, calculated as a given 5-day mean NEE minus mean NEE of previous 5-day interval. Growing season fluxes were quite variable from one 5-day interval to the next, while winter fluxes are more quiescent. Sign convention is that net carbon uptake by peatland is a positive NEE.

region. The first differences ranged from about -1.5 to $+1.5 \mathrm{~g} \mathrm{C} \mathrm{m}^{-2} \mathrm{~d}^{-1}$ during the growing season and were $<0.2 \mathrm{~g} \mathrm{C} \mathrm{m}^{-2} \mathrm{~d}^{-1}$ during the winter (Figure $7 \mathrm{~b}$ ). Model and tower first differences were generally in agreement in both sign and magnitude, though PCARS seemed to vary more strongly than the tower data, particularly during the summer of 1999.

\subsection{Gross $\mathrm{CO}_{2}$ Fluxes}

[44] Total photosynthesis and total respiration (autotrophic plus heterotrophic) are the gross ecosystem $\mathrm{CO}_{2}$ fluxes. These are calculated directly by the model, with NEE determined as their difference. The tower measures NEE directly; nighttime NEE values (when photosynthesis is zero) were used to develop an empirical relationship between ecosystem respiration and temperature for each year. These relationships were used to calculate ecosystem respiration during the daytime, and then photosynthesis was calculated as NEE minus total respiration.

[45] Tower-based total ecosystem respiration rates averaged about $-2.7 \mathrm{~g} \mathrm{C} \mathrm{m}^{-2} \mathrm{~d}^{-1}$ during the summer of 1998 , but dropped by $\sim 33 \%$ during the summer of 1999; winter respiration was about $-0.33 \mathrm{~g} \mathrm{C} \mathrm{m}^{-2} \mathrm{~d}^{-1}$ during $1998-$ 1999 and about $-0.2 \mathrm{~g} \mathrm{C} \mathrm{m}^{-2} \mathrm{~d}^{-1}$ during 1999-2000 

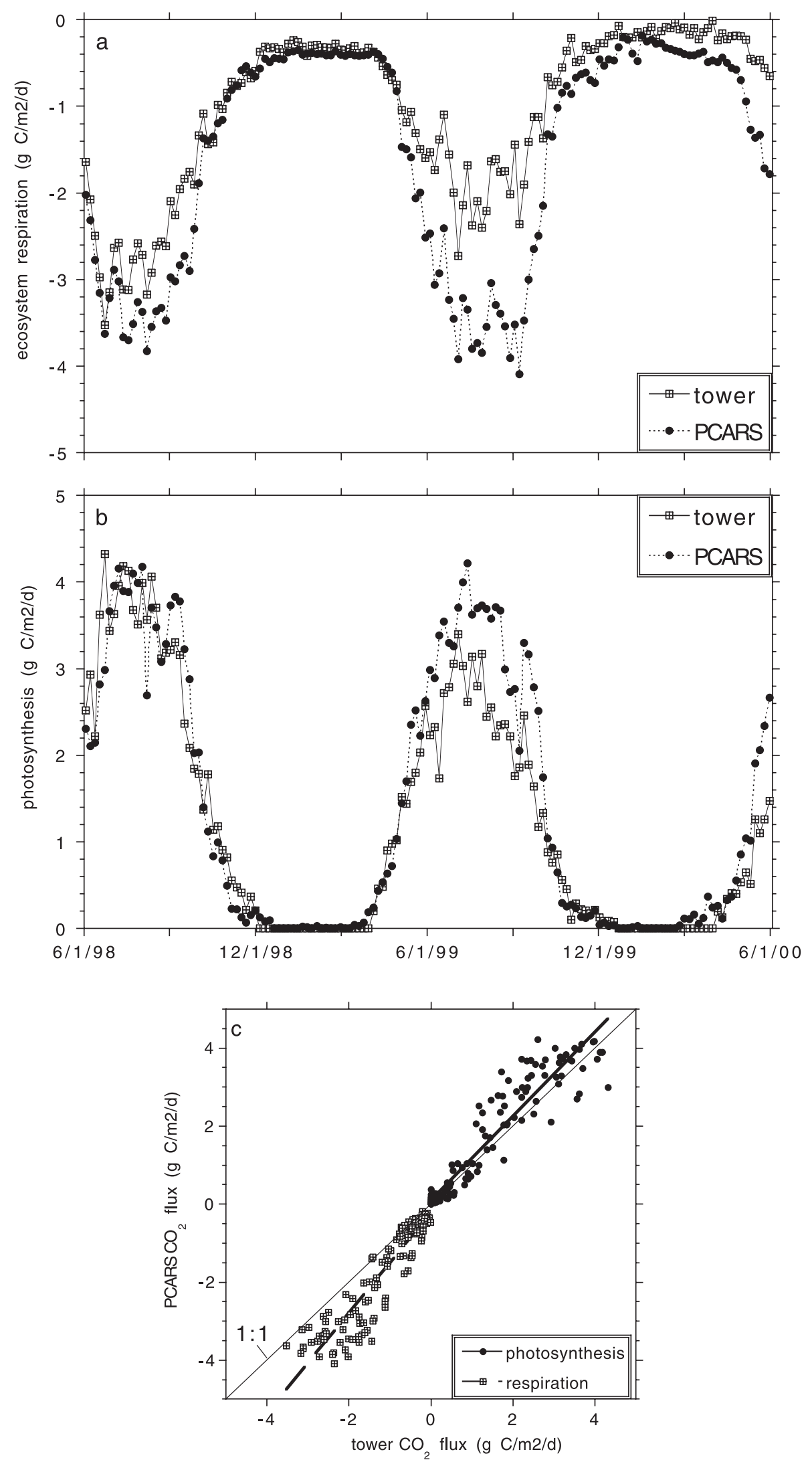

Figure 8. Time series of 5-day mean (a) total ecosystem respiration and (b) total photosynthesis, as calculated from tower flux data and as simulated by PCARS. (c) Scatterplot of 5-day mean respiration and photosynthesis fluxes. 
Table 5. Seasonal Weather and Carbon Flux Means (1998-1999 and 1999-2000) ${ }^{\text {a }}$

\begin{tabular}{|c|c|c|c|c|c|c|c|c|}
\hline \multirow[b]{2}{*}{ Air temperature, ${ }^{\circ} \mathrm{C}$} & \multicolumn{2}{|c|}{ Summer ${ }^{\mathrm{b}}$} & \multicolumn{2}{|c|}{ Fall $^{\mathrm{b}}$} & \multicolumn{2}{|c|}{ Winter $^{\mathrm{b}}$} & \multicolumn{2}{|c|}{ Spring $^{\mathrm{b}}$} \\
\hline & 18.9 & 19.4 & & 8.7 & -7.0 & -7.7 & 6.1 & 6.0 \\
\hline 20 -cm soil temperature, ${ }^{\circ} \mathrm{C}$ & 16.8 & 17.0 & 8.6 & 9.8 & 0.5 & -0.9 & 4.3 & 3.1 \\
\hline Water table depth, $\mathrm{m}$ & -0.37 & -0.41 & -0.29 & -0.3 & -0.25 & -0.21 & -0.22 & -0.21 \\
\hline $\mathrm{PAR}^{\mathrm{c}} \mu \mathrm{mol} \mathrm{m}{ }^{-2} \mathrm{~s}^{-1}$ & 690 & 760 & 480 & 420 & 380 & 340 & 780 & 640 \\
\hline NEE from tower, ${ }^{\mathrm{d}} \mathrm{g} \mathrm{C} \mathrm{m}^{-2} \mathrm{~d}^{-1}$ & 0.80 & 0.72 & 0.19 & 0.03 & -0.32 & -0.14 & 0.10 & 0.18 \\
\hline NEE from PCARS & 0.13 & 0.14 & -0.08 & -0.46 & -0.4 & -0.32 & 0.00 & 0.02 \\
\hline Respiration from tower, $\mathrm{g} \mathrm{C} \mathrm{m}^{-2} \mathrm{~d}^{-1}$ & -2.74 & -1.87 & -1.3 & -1.65 & -0.33 & -0.15 & -0.73 & -0.26 \\
\hline Respiration from PCARS & -3.23 & -3.34 & -1.64 & -1.65 & -0.43 & -0.34 & -0.93 & -0.79 \\
\hline Photosynthesis from tower, $\mathrm{g} \mathrm{C} \mathrm{m}^{-2} \mathrm{~d}^{-1}$ & 3.54 & 2.62 & 1.50 & 0.89 & 0.01 & 0.01 & 0.84 & 0.46 \\
\hline Photosynthesis from PCARS & 3.36 & 3.48 & 1.55 & 1.19 & 0.03 & 0.02 & 0.93 & 0.81 \\
\hline
\end{tabular}

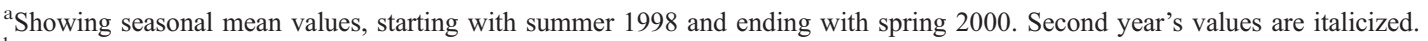

${ }^{\mathrm{b}}$ Summer, June-August; Fall, September-November; Winter, December-February; Spring, March-May.

${ }^{c}$ Average of daytime values only (PAR $>10 \mu \mathrm{mol} \mathrm{m}^{-2} \mathrm{~s}^{-1}$ ).

${ }^{\mathrm{d}}$ Net ecosystem exchange.

(Figure 8a and Table 5). Tower-based seasonal mean respiration rates were smaller in the second winter and spring and larger in the second fall, tracking changes in soil temperature, but with very strong apparent sensitivity (Table 5). PCARS summertime respiration was about -3.3 $\mathrm{g} \mathrm{C} \mathrm{m}^{-2} \mathrm{~d}^{-1}$ during both years, and winter respiration was about -0.3 to $-0.4 \mathrm{~g} \mathrm{C} \mathrm{m}^{-2} \mathrm{~d}^{-1}$ during both winters (Figure 8a and Table 5). Air and soil temperatures were slightly warmer during the summer of 1999, and the average water table was slightly deeper, primarily because of a very dry period in August 1999 (Table 5).
[46] The surface peat $(0-0.2 \mathrm{~m})$ accounted for about two thirds of the total decomposition during the drier summers of 1998 and 1999 and accounted for $\sim 80 \%$ of the total decomposition during the wetter summer of 2000 (Figure 9). This peat was the most readily decomposable (equation (8)) [see also Frolking et al., 2001], was the warmest during the summer, and remained unsaturated and aerobic during the growing season. Peat below $0.5 \mathrm{~m}$ was almost always saturated and was assumed to be anaerobic. Despite accounting for $90 \%$ of the total peat mass, its greater recalcitrance and less favorable temper-

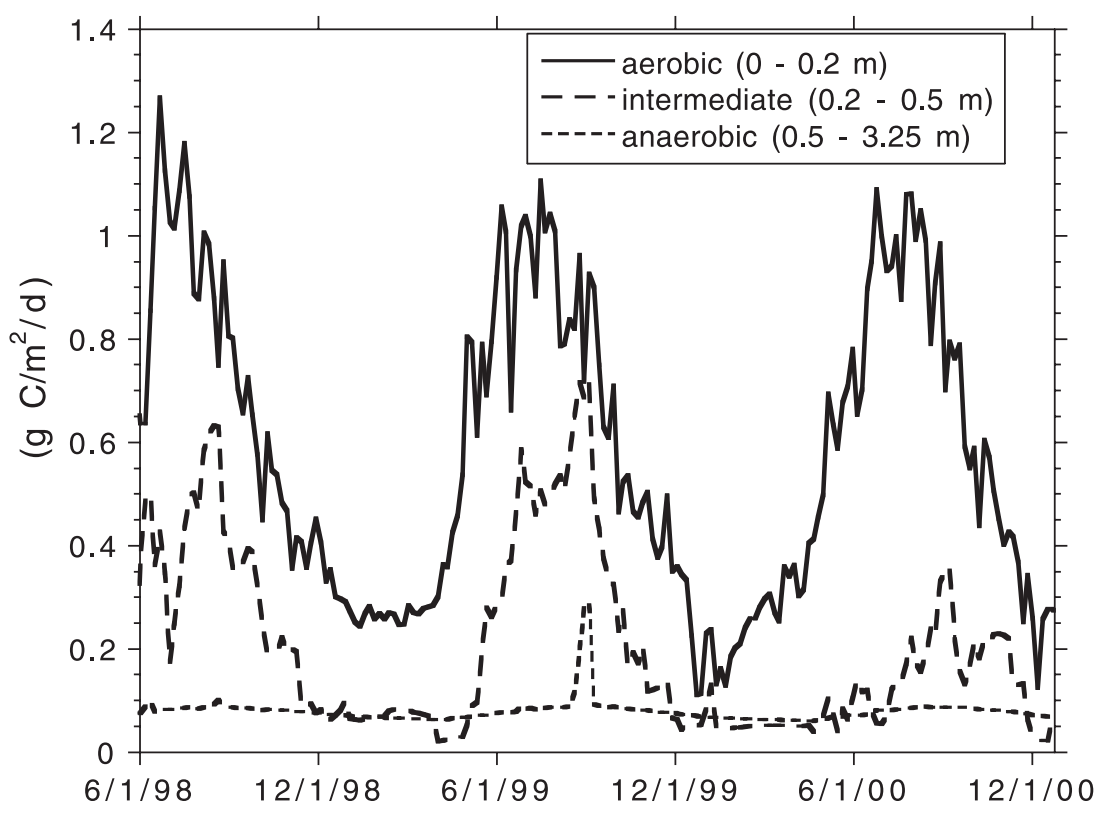

Figure 9. Time series of 5-day mean decomposition rates for three depth intervals in peat profile. Surface peat $(0-0.2 \mathrm{~m})$ was never saturated during growing season. Deepest peat $(0.5 \mathrm{~m}$ to bottom) was saturated during most of simulation and decomposed slowly, except for a short dry period in summer 1999, which caused a brief increase in decomposition over that depth range. Middle layer $(0.2-0.5 \mathrm{~m})$ was zone in which fluctuating water table was usually found. During wetter summer of 2000 (see Figure 4c), decomposition in middle layer was much less than in previous two summers. Note that this graph portrays total decomposition (i.e., C loss from peat), some of which generates DOC losses, some of which generates methane in anaerobic zone, and most of which is emitted as $\mathrm{CO}_{2}$. Note that Figure 9 does not follow sign convention for ecosystem exchange of $\mathrm{CO}_{2}$. 
ature and moisture conditions caused it to contribute only $\sim 7 \%$ of total decomposition during the growing season (May-October) and 18\% during the winter (DecemberMarch) (Figure 9). The peat in the zone of water table variation $(0.2-0.5 \mathrm{~m})$ had the greatest interannual variation in decomposition (Figure 9) in response to wetter or drier weather conditions (Figure 4c).

[47] Gross photosynthesis during the 1998 summer was estimated to average $\sim 3.4-3.5 \mathrm{~g} \mathrm{C} \mathrm{m}^{-2} \mathrm{~d}^{-1}$ from the tower data and by PCARS; on the basis of the tower flux data, photosynthesis during the summer of 1999 averaged around $2.6 \mathrm{~g} \mathrm{C} \mathrm{m}^{-2} \mathrm{~d}^{-1}$, while PCARS predicted a higher rate of $\sim 3.5 \mathrm{~g} \mathrm{C} \mathrm{m}^{-2} \mathrm{~d}^{-1}$ (Figure $8 \mathrm{~b}$ and Table 5). PCARS predicted that the onset of photosynthesis in the spring occurred in early April, but the tower data analysis indicated that some photosynthesis occurred during March. In the autumn, photosynthetic rates declined rapidly during October, were very low during November, and fell to zero during early December. Since NEE was similar in both years but the tower-based estimate for respiration was significantly less in the second year, the tower-based estimates for seasonal photosynthetic rates were also less in the second year, though these did not correlate with changes in seasonal mean air temperature, water table depth, or PAR (Table 5). PCARS simulated little difference in photosynthesis between 1998 and 1999, except during the fall seasons. Coefficients of determination for photosynthesis and respiration rose from 0.85 to $0.9-0.95$ as the averaging interval rose from 1 day to 1 month (see also Figure 8c).

\subsection{Methane and DOC}

[48] PCARS simulated methane production year round, ranging from $45-70 \mathrm{mg} \mathrm{CH} \mathrm{Cm}^{-2} \mathrm{~d}^{-1}(0.034-0.053 \mathrm{~g} \mathrm{C}$ $\mathrm{m}^{-2} \mathrm{~d}^{-1}$ ), corresponding to $\sim 10 \%$ of heterotrophic respiration in the winter and 3\% in the summer. Mer Bleue is a relatively dry bog, with a deep water table $(0.25-0.7$ $\mathrm{m}$ in the summer), and this had two consequences for methane production and flux. First, a deep water table meant that the saturated peat was old and relatively decomposed, and thus was decomposing slowly (equation (8)), so methane production was limited. Second, because there was a thick oxidation zone above the water table, most methane was oxidized before it diffused to the atmosphere, and methane fluxes were negligible during the summer months and low the rest of the year. Annual methane fluxes were 390, 710, and $750 \mathrm{mg} \mathrm{CH}$ $\mathrm{m}^{-2} \mathrm{yr}^{-1}\left(0.29,0.53\right.$, and $\left.0.56 \mathrm{~g} \mathrm{C} \mathrm{m}^{-2} \mathrm{yr}^{-1}\right)$ in 1998 , 1999 , and, 2000, respectively. This was $<0.1 \%$ of gross carbon fluxes and $\sim 1 \%$ on the net carbon exchange. Static chamber flux measurements were conducted occasionally during the summers of 1998 and 1999 at Mer Bleue. Fluxes were generally quite low, ranging between a maximum net emission of $+22 \mathrm{mg} \mathrm{CH}_{4} \mathrm{~m}^{-2} \mathrm{~d}^{-1}$ and a maximum net uptake of $-5.0 \mathrm{~g} \mathrm{CH}_{4} \mathrm{~m}^{-2} \mathrm{~d}^{-1}$. Average fluxes on the measurement days ranged from +5.5 to $-2.2 \mathrm{mg} \mathrm{CH}_{4} \mathrm{~m}^{-2} \mathrm{~d}^{-1}$.

[49] PCARS did not simulate DOC production and flux, but used site data to estimate DOC losses and subtracted this from the decomposition totals before estimating $\mathrm{CO}_{2}$ emis- sions. Calendar year DOC losses were $11 \mathrm{~g} \mathrm{C} \mathrm{m}^{-2} \mathrm{yr}^{-1}$ in $1998,10 \mathrm{~g} \mathrm{C} \mathrm{m}^{-2} \mathrm{yr}^{-1}$ in 1999 , and $14 \mathrm{~g} \mathrm{C} \mathrm{m}^{-2} \mathrm{yr}^{-1}$ in 2000 , based on an empirical relationship between runoff and DOC concentration [Fraser et al., 2001] and input data on horizontal drainage.

\subsection{Annual Component $C$ Balances}

[50] We aggregated PCARS component fluxes to annual budgets for shrub and moss photosynthesis and respiration and heterotrophic decomposition $\left(\mathrm{CO}_{2}+\mathrm{CH}_{4}+\right.$ DOC). Since the model had a full 3-year simulation, we based these aggregations on calendar year totals. Total photosynthesis was $\sim 500 \mathrm{~g} \mathrm{C} \mathrm{m}^{-2}$ each year, but somewhat more in 2000 due to greater moss photosynthesis (Figure 10). Ecosystem respiration was more variable, ranging from 500 to $600 \mathrm{~g} \mathrm{C} \mathrm{m}^{-2} \mathrm{yr}^{-1}$; the largest single variation was the $\sim 15 \%$ drop in decomposition in 2000. Shrub NPP was $180-200 \mathrm{~g} \mathrm{C} \mathrm{m}^{-2} \mathrm{yr}^{-1}$, and moss NPP was $60-90 \mathrm{~g} \mathrm{C} \mathrm{m}^{-2} \mathrm{yr}^{-1}$. PCARS predicted a net loss of $\sim 40 \mathrm{~g} \mathrm{C} \mathrm{m}^{-2} \mathrm{yr}^{-1}$ in 1998 and $\sim 80 \mathrm{~g} \mathrm{C} \mathrm{m}^{-2}$ $\mathrm{yr}^{-1}$ in 1999 and a net gain of $\sim 30 \mathrm{~g} \mathrm{C} \mathrm{m}^{-2} \mathrm{yr}^{-1}$ in 2000. Annual net ecosystem productivity was $5-15 \%$ of the gross ecosystem fluxes.

\subsection{Model Sensitivities}

[51] We ran a series of sensitivity simulations, adjusting PCARS parameters that influence either autotrophic or heterotrophic respiration (Table 6). To summarize the results, we calculated seasonal mean ecosystem respiration (Figure 11a) and seasonal mean vegetation NPP rates (Figure 11b). All sensitivity effects were quite small. The biggest impact on total ecosystem respiration was a $6 \%$ increase (decrease) due to a $30 \%$ increase (decrease) in the foliar base respiration rate. Changes in decomposition parameters (sensitivity runs $\mathrm{s} 1-\mathrm{s} 14$ ) had only small effects on ecosystem respiration. Changing parameters that affect litter decomposition directly ( $k_{0}$ and $f_{\text {anox }}$ ) caused significant changes in the mass of the total peat profile during the initialization calculation (Table 6), so if $k_{0}$ was reduced by $25 \%$ there was an increase in peat mass, and the larger peat mass decaying at a slower rate led to approximately the same total decomposition and heterotrophic respiration. Changing the parameters that affected the temperature and moisture controls on decomposition also had little effect, because these multiplicative factors are standardized to generate an initial mass loss that is consistent with litterbag studies. The first seven parameters affected only decomposition and thus had no effect on NPP when they were increased or decreased. Increasing (decreasing) the foliar base respiration rate by $30 \%$ decreased (increased) summer NPP by $9 \%$. Changing the $Q_{10}$ for autotrophic respiration by $20 \%$ changed NPP by $2-3 \%$.

[52] We also tested model sensitivity to water table depth, $z_{\mathrm{WT}}$, in a pair of simulations that added (subtracted) a constant $0.1 \mathrm{~m}$ to the input value of $z_{\mathrm{WT}}$ each hour of the simulation. We estimate that the combined variability and uncertainty in $z_{\mathrm{WT}}$ over the scale of the eddy covariance tower footprint is roughly $0.1 \mathrm{~m}$. Fraser [1999] showed that the spatial variability in the height of the water table relative to the peat surface within several hundred meters 


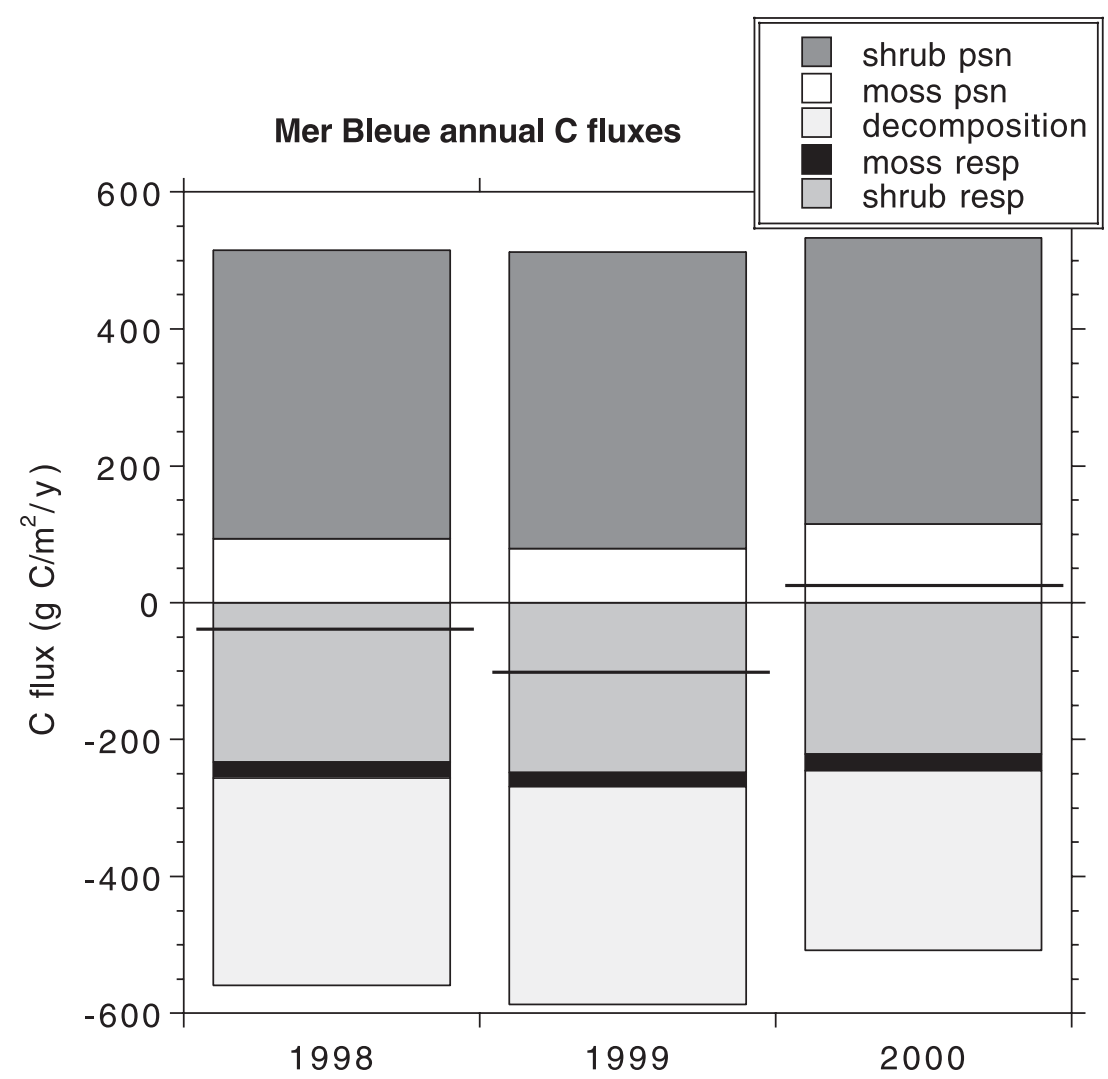

Figure 10. Annual fluxes of carbon as predicted by PCARS for calendar years 1998, 1999, and 2000. Total photosynthesis was $\sim 520 \mathrm{~g} \mathrm{C} \mathrm{m}^{-2} \mathrm{yr}^{-1}$, with shrubs fixing $\sim 80-85 \%$ of this carbon and with mosses fixing $\sim 15-20 \%$. Decomposition flux includes $\sim 10 \mathrm{~g} \mathrm{C} \mathrm{m}^{-2} \mathrm{yr}^{-1}$ of DOC loss and includes $<1$ g C m${ }^{-2} \mathrm{yr}^{-1}$ as $\mathrm{CH}_{4}$ flux. Total respiration was more variable from year to year than photosynthesis. Autotrophic and heterotrophic respiration each contributed approximately half of total respiration. Annual net ecosystem carbon flux, represented by thick horizontal bars, was calculated as the sum of the five contributing fluxes. In 1998 and 1999, PCARS predicted that Mer Bleue Bog had a net loss of carbon of $\sim 50$ and $\sim 100 \mathrm{~g} \mathrm{C} \mathrm{m}^{-2} \mathrm{yr}^{-1}$, respectively, and had a net gain of $\sim 20 \mathrm{~g} \mathrm{C} \mathrm{m}^{-2}$ $\mathrm{yr}^{-1}$ in 2000 .

of the tower varied by $\sim 0.15 \mathrm{~m}$ and that the changes in water table were highly correlated regardless of location on the peatland. In addition, the microtopography of the bog surface, hummocks and hollows, has an amplitude of roughly $0.25 \mathrm{~m}$ [Remier, 2001]; PCARS does not simulate this microtopography; we set the model bog surface at $\sim 0.1 \mathrm{~m}$ below the hummock surface and $0.15 \mathrm{~m}$ above the hollow surface.

[53] Averaged over the 3-year simulation, sensitivities to increased and decreased water table depth were approximately symmetric (Table 7). Gross flux sensitivities (<8\%) were comparable to the largest parameter sensitivities (Figure 11). The most sensitive components were moss photosynthesis and respiration and decomposition. The magnitude of decomposition was much greater than moss NPP (see Figure 10), so overall NEE increased with a shallower water table, such that the site would have been a carbon sink in all three simulation years, with an average annual uptake of $50 \mathrm{~g} \mathrm{C} \mathrm{m}^{-2}$. A deeper water table led to increased respiration and an average annual NEE of -100 $\mathrm{g} \mathrm{C} \mathrm{m}{ }^{-2}$. Because NEE is the difference between gross photosynthesis and total respiration, its percentage sensitivity could be quite high, and so absolute changes were reported (Table 7). These changes were comparable to the range in interannual variability estimated by PCARS

Table 6. Parameters Adjusted in Sensitivity Simulations

\begin{tabular}{llrrr}
\hline \multicolumn{1}{c}{ Run } & Parameter Adjusted & Change & Peat, $^{\mathrm{a}} \mathrm{kg}$ & Annmod $^{\mathrm{b}}$ \\
\hline Base & - & - & 288 & 6800 \\
s1, s2 & shrub $k_{0}$ & $\pm 25 \%$ & 242,359 & 6800,6800 \\
s3, s4 & moss $k_{0}$ & $\pm 25 \%$ & 255,339 & 6800,6800 \\
s5, s6 & $f_{\text {anox }}$ & $\pm 50 \%$ & 244,364 & 6800,6800 \\
s7, s8 & $\mathrm{W}^{*}$ & $\pm 33 \%$ & 288,288 & 5750,8000 \\
s9, s10 & $f(W)$ exp & $\pm 50 \%$ & 288,288 & 6800,6800 \\
s11, s12 & heterotrophic $T_{\min }$ & $\pm 2{ }^{\circ} \mathrm{C}$ & 288,288 & 6430,6880 \\
s13, s14 & heterotrophic $Q_{10}$ & $\pm 20 \%$ & 288,288 & 7370,6300 \\
s15, s16 & foliar base & $\pm 30 \%$ & 288,288 & 6800,6800 \\
& $\quad$ respiration rate & & & \\
s17, s18 & autotrophic $T_{\min }$ & $\pm 2{ }^{\circ} \mathrm{C}$ & 288,288 & 6800,6800 \\
s19, s20 & autotrophic $Q_{10}$ & $\pm 20 \%$ & 288,288 & 6800,6800 \\
\hline
\end{tabular}

${ }^{\mathrm{a}}$ Mass of peat in profile initialization.

${ }^{\mathrm{b}}$ Annual sum of hourly product of decomposition rate multipliers at $5 \mathrm{~cm}$ $\left(f_{d}\left(T_{i}\right) \cdot f_{d}\left(W_{i}\right)\right.$ in equation $\left.(9)\right)$. 

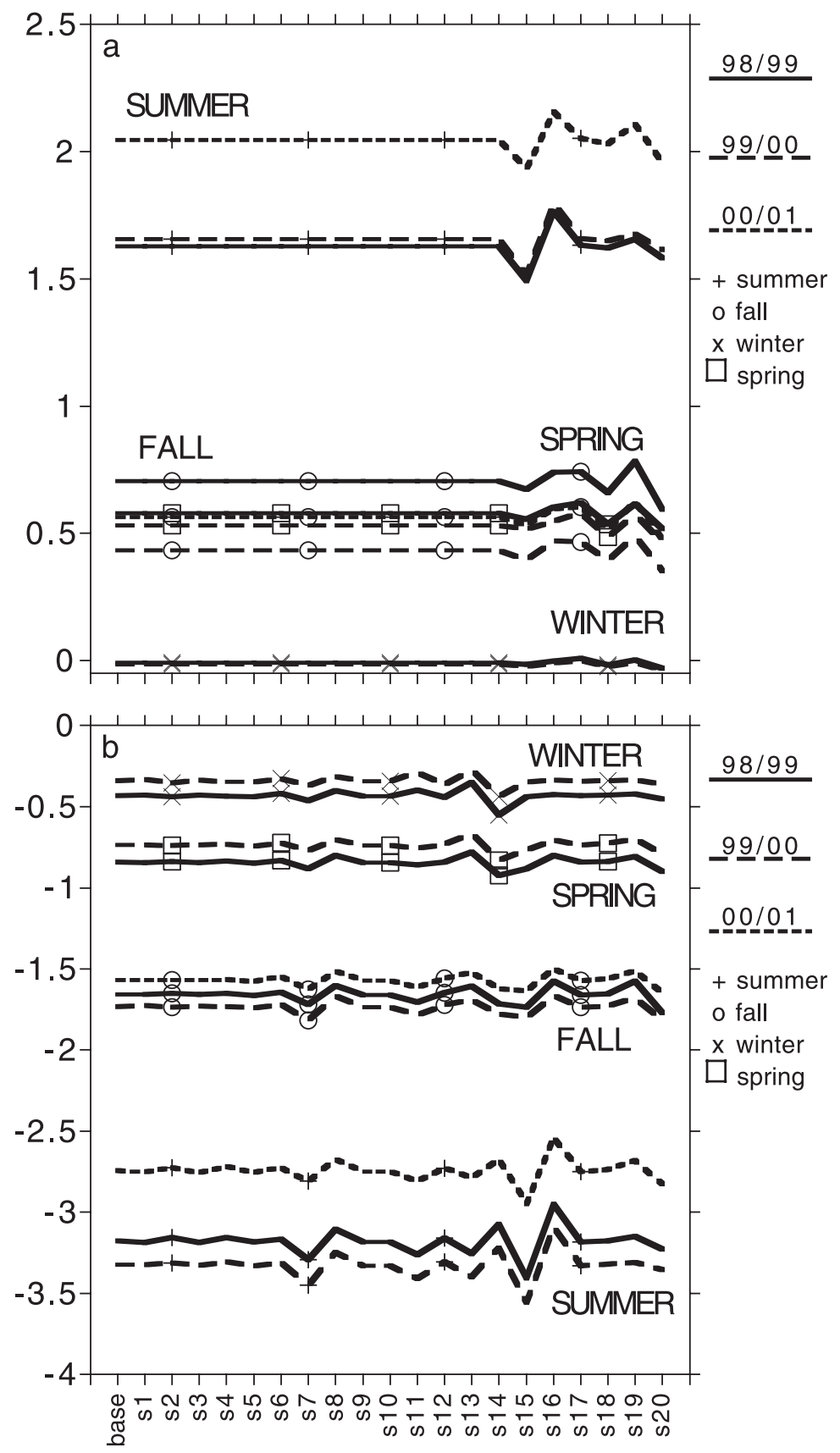

Figure 11. Sensitivity of seasonal mean $C$ fluxes of (a) total ecosystem respiration and (b) vegetation NPP, as individual parameters influencing autotrophic or heterotrophic respiration were varied (see Table 6). Solid lines represent seasonal fluxes for June 1998 through May 1999, long-dashed lines represent seasonal fluxes for June 1999 through May 2000, and short-dashed lines represent seasonal fluxes for June-November 2000. Overall sensitivities were small, despite large percentage changes in parameter values. Sign convention is that net carbon uptake by peatland is a positive NEE. Summer is June-August, fall is September-November, winter is December-February, and spring is March-May.

(Figure 10). (Note that Table 7 reports changes in the annual mean carbon fluxes.)

\section{Discussion and Conclusions}

[54] PCARS estimates of annual net primary productivity (NPP) averaged, $190 \pm 6 \mathrm{~g} \mathrm{C} \mathrm{m}^{-2} \mathrm{yr}^{-1}$ for shrub and
$74 \pm 17 \mathrm{~g} \mathrm{C} \mathrm{m}^{-2} \mathrm{yr}^{-1}$ for moss vegetation over the 3-year simulation ( \pm 1 standard deviation). Shrub NPP was primarily belowground (76\%) because aboveground NPP was limited to one half of the maximum leaf biomass (Table 2), to be consistent with a 2-year leaf retention time for the ericaceous shrubs. PCARS estimated that heterotrophic respiration was $52 \pm 2 \%$ of total ecosystem respiration. 
Table 7. Changes in PCARS Mean Annual Carbon Flux Due to a \pm 0.1 -m Change in Water Table Depth, Based on 3-Year Simulation

\begin{tabular}{|c|c|c|}
\hline & Shallower & Deeper \\
\hline Total photosynthesis & $+5 \%$ & $-8 \%$ \\
\hline Mosses & $+22 \%$ & $-27 \%$ \\
\hline Shrubs & $+1 \%$ & $-4 \%$ \\
\hline Total respiration & $-8 \%$ & $+8 \%$ \\
\hline Mosses & $+13 \%$ & $-20 \%$ \\
\hline Shrubs & $+1 \%$ & $-3 \%$ \\
\hline Heterotrophs & $-18 \%$ & $+19 \%$ \\
\hline NEE, $\mathrm{g} \mathrm{C} \mathrm{m}^{-2}$ & +72 & -85 \\
\hline
\end{tabular}

Moore et al. [2002] constructed a carbon budget for Mer Bleue on the basis of field measurements of biomass and literature-based estimates of mass-based productivity and respiration. They concluded that shrub NPP was $\sim 250 \mathrm{~g} \mathrm{C}$ $\mathrm{m}^{-2} \mathrm{yr}^{-1}$, with $\sim 70 \%$ belowground, that moss NPP was $\sim 70 \mathrm{~g} \mathrm{C} \mathrm{m}^{-2} \mathrm{yr}^{-1}$, and that heterotrophic respiration was $48 \%$ of total ecosystem respiration. These values are within the range of published NPP values for boreal and cool temperate bogs: Thormann and Bayley [1997] report mean aboveground NPP of $60 \mathrm{~g} \mathrm{C} \mathrm{m}^{-2} \mathrm{yr}^{-1}$ for shrubs and $95 \mathrm{~g} \mathrm{C}$ $\mathrm{m}^{-2} \mathrm{yr}^{-1}$ for mosses in bogs in western Canada. Campbell et al. [2000], in a synthesis of published NPP data for wetlands in western Canada, reported mean NPP of nonpermafrost bogs as $225 \mathrm{~g} \mathrm{C} \mathrm{m}^{-2} \mathrm{yr}^{-1}$, with $75 \mathrm{~g} \mathrm{C} \mathrm{m}^{-2} \mathrm{yr}^{-1}$ due to moss production and $150 \mathrm{~g} \mathrm{C} \mathrm{m}^{-2} \mathrm{yr}^{-1}$ due to vascular plant production. Smith and Forrest [1978] reported mean NPP of $270 \mathrm{~g} \mathrm{C} \mathrm{m}^{-2} \mathrm{yr}^{-1}$ for vascular plants and $59 \mathrm{~g} \mathrm{C} \mathrm{m}^{-2} \mathrm{yr}^{-1}$ for Sphagnum at Moor House in the United Kingdom. Belyea and Warner [1996] reported total aboveground and belowground productivity of $220-$ $465 \mathrm{~g} \mathrm{C} \mathrm{m}^{-2} \mathrm{yr}^{-1}$ for a Sphagnum and ericaceous shrubdominated bog in western Ontario.

[55] Valentini et al. [2000] found that differences in ecosystem respiration explained much more of the variation in tower-based measurements of annual ecosystem NEE across 15 European forest stands than did differences in photosynthesis. Thus it is important to try to understand the causes of any differences between modeled and measured respiration. There are four possible sources for PCARS' bias toward ecosystem respiration relative to the tower: The model underestimated photosynthesis, it overestimated plant (shrub and/or moss) respiration, it overestimated decomposition, and/or the tower underestimated ecosystem respiration. Since PCARS 5-day mean photosynthesis was generally equal to or larger than the tower estimate (Figure $8 \mathrm{~b})$, the bias was not likely because of the model underestimating photosynthesis. PCARS estimates of shrub NPP, calculated as annual photosynthesis minus annual autotrophic respiration (leaf, stem, and root respiration,) were slightly lower than the estimate of Moore et al. [2002] for the same site, implying that shrub respiration may have been overestimated by PCARS. One possible source of this difference is the PCARS dormancy function, which modifies respiration rates early and late in the growing season. This important function does not have a strong empirical foundation in peatland ecophysiological data. The difference in NPP estimates, $\sim 60 \mathrm{~g} \mathrm{C} \mathrm{m}^{-2} \mathrm{yr}^{-1}$, would average $\sim 0.5 \mathrm{~g} \mathrm{C} \mathrm{m}^{-2} \mathrm{~d}^{-1}$ during a 4-month growing season. This is about the difference between PCARS and tower respiration estimates during the first summer and fall, but is much less than the difference during the second summer (Table 5). Field-based and PCARS moss NPP estimates were similar, so PCARS moss respiration rates were not likely to be a significant overestimate. There is no independent check of heterotrophic respiration rates, so a PCARS overestimation of these cannot be ruled out. The relationships between tower $\mathrm{CO}_{2}$ flux and soil temperature were not strong. The standard error of these empirical models of respiration was up to about $\pm 40 \%$ of the average measured flux, so the discrepancy between model and tower respiration estimates (Figure 8a) was probably generally within the uncertainty of the field-based estimate. Opaque chamber measurements of midday ecosystem respiration, made on 8-9 July 1999, ranged from about -3 to $-5 \mathrm{~g} \mathrm{C} \mathrm{m}^{-2} \mathrm{~d}^{-1}$ [Moore et al., 2002], somewhat greater than the 5-day average respiration of the tower $\left(-2.1 \mathrm{~g} \mathrm{C} \mathrm{m}^{-2} \mathrm{~d}^{-1}\right)$ or the model $\left(-3.2 \mathrm{~g} \mathrm{C} \mathrm{m}^{-2} \mathrm{~d}^{-1}\right)$. This may be expected because of generally warmer soil temperatures for midday measurements than for 5-day averages. Interpreting this type of model/tower bias will always be problematic. The model first calculates photosynthesis and respiration and then calculates NEE as their difference, while the tower measures NEE, empirically estimates respiration from a subset of the observations, and then calculates photosynthesis as a difference. Thus first-order calculations are compared to second-order observations, and second-order calculations are compared to first-order observations.

[56] There is no clear reason why summer 1999 ecosystem respiration rates, derived from measurements of NEE, would be $\sim 30 \%$ lower than summer 1998 ecosystem respiration rates. Mean air and soil temperatures were slightly warmer and the mean water table was slightly deeper in 1999 (Table 5), all of which should enhance respiration slightly. In addition, mean $P A R$ insolation was also larger in 1999, which could also lead to increased photosynthesis and, perhaps, to more autotrophic respiration. PCARS simulated 3\% more ecosystem respiration in 1999 because of these factors. There was a very dry period in the summer of 1999 , and the water table dropped to $\sim 0.6$ $\mathrm{m}$, but tower ecosystem respiration rates were already lower by early June 1999, before this significant drying had happened. Because tower NEE was similar during the summers of 1998 and 1999 while respiration declined substantially in 1999, the tower-estimated photosynthetic rates in the summer of 1999 were also much lower $(\sim 25 \%)$ than in summer of 1998. PCARS, however, estimated a $4 \%$ increase in photosynthesis, primarily because of slightly higher mean PAR in 1999. PCARS did simulate a $15 \%$ decline in ecosystem respiration during the summer of 2000 , compared with the summer of 1998. Most of this was due to a reduction in heterotrophic respiration (decomposition) due to a shallower water table in 2000 and thus a smaller zone for aerobic decomposition.

[57] The eddy covariance tower measured smaller winter respiration rates in the second winter (1999-2000) than the first winter, probably associated with colder soil temperatures, caused by a delayed arrival of the winter snowpack. 
Soil temperatures at $0.2 \mathrm{~m}$ averaged $\sim 1.3^{\circ} \mathrm{C}$ colder during the second winter (December/January/February) than during the first, and air temperature was $0.7^{\circ} \mathrm{C}$ colder during the second winter. Ecosystem respiration was $>50 \%$ lower during the second winter than during the first, implying a very strong temperature response at near-freezing temperatures that is not captured in the PCARS formulation (equation (10)). The empirical relationships between ecosystem respiration and soil temperature derived from the tower data had $Q_{10}$ values of 3.0 for year 1 and 4.8 for year 2, while all components of PCARS respiration had $Q_{10}=2$ (Table 1). This weaker temperature response may be why PCARS simulated very similar respiration rates in both winters, despite being driven by observed soil and air temperatures.

[58] PCARS is the first peatland model to directly link contemporary carbon fluxes to the long-term carbon balance by using surface NPP as an input to its long-term accumulation calculation and by using observed fresh litter decomposition rates to determine peat decomposition rates down the peat profile [Frolking et al., 2001]. The general processes of production and decomposition are not likely to have changed over the lifetime of the peatland, though process rates and vegetation types undoubtedly varied. Thus a process-based model must have a consistent formulation for the process controlling long-term accumulation and contemporary fluxes. PCARS was designed with this in mind, though the long-term accumulation/peat profile initialization makes simplifying assumptions to minimize the variability in process rates [Frolking et al., 2001]. This consistency between the processes controlling contemporary carbon fluxes and the long-term carbon balance provides a major constraint on model behavior, because any change that would cause a significant shift in the contemporary carbon fluxes will also cause a shift in long-term peat accumulation, which in turn feeds back to dampen the effect on the contemporary flux. This led to PCARS being fairly insensitive to the value of a number of the parameters controlling components of ecosystem respiration and also led to a similar insensitivity to factors controlling ecosystem production.

[59] Methane production at Mer Bleue was estimated by PCARS to be $\sim 45-70 \mathrm{mg} \mathrm{CH} \mathrm{Cm}^{-2} \mathrm{~d}^{-1}$. The methane concentration in the peat pore water was simulated to be $\sim 0.5 \mathrm{mmol}$, below the PCARS threshold for ebullition. Diffusive losses from the dissolved methane pool were estimated to be $\sim 50-60 \mathrm{mg} \mathrm{CH}_{4} \mathrm{~m}^{-2} \mathrm{~d}^{-1}$, so the dissolved pool concentration was relatively stable. Most of the methane that diffused out of the pore water was oxidized in the unsaturated surface peat before it could escape to the atmosphere, and surface methane fluxes were quite low, consistent with summer season chamber measurements at the site. The only period of moderate fluxes $\left(\sim 20 \mathrm{CH}_{4} \mathrm{~m}^{-2}\right.$ $\mathrm{d}^{-1}$ ) was during the high water table period in the spring of 1999; measurements at the end of this period showed negligible flux. Overall, methane played a very small role in the Mer Bleue carbon budget, and this did not provide a strenuous test of the model. Most other models of peatland methane fluxes [e.g., Walter and Heimann, 2000; Granberg, 1998; Frolking and Crill, 1994] have been parameterized to match total annual fluxes and have focused on climatic controls on the temporal variability in fluxes. Walter and Heimann [2000] and Granberg [1998] treat the peat soil profile in detail, modeling methane concentration gradients and vertical diffusion of methane. In developing PCARS, we were more interested in simulating the seasonal to annual production and flux of methane as a component of the ecosystem carbon budget than in simulating highfrequency temporal variability and the occasionally episodic nature of methane fluxes. Potter [1997] also simulated methane production and emission directly, relating methane production to total decomposition as a function of water table depth. That model did not link methane production in each of its soil layers to the water content of that layer, so, as in PCARS, the methane pool was not vertically disaggregated.

[60] We believe that the major sources of uncertainty in the model parameterization are related to controls on decomposition. These include (1) the appropriate water table depth datum for comparison between model and tower, and the role of hummocks and hollows in determining this datum; (2) the impact of peat water content, which is a function of water table depth and peat structure, on its decomposition $\left(f_{d}\left(W_{i}\right)\right.$ in equation (9)) (the current formulation in PCARS has been based on the standard functional form for mineral soils); (3) the initial mass loss rates for belowground tissues (fine roots), for which we have only preliminary data from Mer Bleue indicating that they are similar to the rates for aboveground foliage; (4) the effect of long-term anoxia on suppressing decomposition in the deep peat $\left(f_{\text {anox }}\right.$ in Table 1$)$, which we have modeled as stronger than has been observed in incubation studies [see Frolking et al., 2001]; and (5) the parameterization for the increase in recalcitrance as litter/peat decomposes (equation (8)). Clymo et al. [1998] analyzed several hundred age-depth profiles from Finnish peat cores and found that the data could not readily discriminate between several different formulations.

[61] In addition to further work to better parameterize or represent these model components, PCARS is being linked to CLASS and a single column GCM to couple the carbon cycle with a climate model. In order to improve the realism of the profile initiation, we will couple the PCARS initialization routine [Frolking et al., 2001] with a dynamic peat accumulation model [Hilbert et al., 2000] that can simulate the impact of varying environmental conditions over the millennia of peatland development. After further testing at other instrumented northern peatland sites in North America and Eurasia, PCARS will be extended to regional and global-scale simulations. We anticipate several challenges in extrapolating PCARS to this scale, primarily related to mapping the distribution and vegetation communities of northern peatlands. For some areas, peatlands are well mapped [e.g., Vitt et al., 1997; Halsey et al., 1995], but for others they are not. A second major challenge will be to measure or simulate the spatiotemporal dynamics of peatland water table depth across the range of northern peatlands. Remote sensing has the potential to map inundation at large scales and with high resolution [e.g., Milne et al., 2000], but is less capable of mapping water tables below the surface. 
[62] Acknowledgments. This work has been supported by a grant from the NASA Terrestrial Ecology's BOREAS Guest Investigator Program to S.F. and P.M.C., a grant to J.L.B. from NASA's New-Investigator Program in Earth Science, and a Canadian NSERC strategic grant to N.T.R., T.R.M., and P.L.. We thank Liz Burrows for collecting the phenology data at Sallie's Fen.

\section{References}

Aber, J. D., and C. A. Federer, A generalized, lumped parameter model of photosynthesis, evapotranspiration and net primary production in temperate and boreal forest ecosystems, Oecologia, 92, 463-474, 1992.

Alm, J., L. Schulman, J. Walden, H. Nykänen, P. J. Martikainen, and J. Silvola, Carbon balance of a boreal bog during a year with an exceptionally dry summer, Ecology, 80, 161-174, 1999.

Anisimov, O. A., N. I. Shiklomanov, and F. E. Nelson, Effects of global warming on permafrost and active layer thickness: Results from transient general circulation models, Global Planet. Change, 15, 61-77, 1997.

Apps, M. J., W. A. Kurz, R. J. Luxmoore, L. O. Nilsson, R. A. Sedjo, R. Schmidt, L. G. Simpson, and T. S. Vinson, Boreal forests and tundra, Water Air Soil Pollut., 70, 39-53, 1993.

Bartlett, K. B., and R. C. Harriss, Review and assessment of methane emissions from wetlands, Chemosphere, 26, 261-320, 1993.

Bartsch, I., and T. R. Moore, A preliminary investigation of primary production and decomposition in four peatlands near Schefferville, Québec, Can. J. Bot., 63, 1241-1248, 1985.

Belyea, L. R., Separating the effects of litter quality and macroenvironment on decomposition rates in a patterned peatland, Oikos, 77, 529-539, 1996.

Belyea, L. R., and B. G. Warner, Temporal scale and the accumulation of peat in a Sphagnum bog, Can. J. Bot., 74, 366-377, 1996.

Bubier, J. L., T. R. Moore, L. Bellisario, N. T. Comer, and P. M. Crill, Ecological controls on methane emissions from a northern peatland complex in the zone of discontinuous permafrost, Manitoba, Canada, Global Biogeochem. Cycles, 9, 455-470, 1995.

Busby, J. R., L. C. Bliss, and C. D. Hamilton, Microclimate control of growth rates and habitats of the boreal forest mosses, Tomenthypnum nitens and Hylocomium splendens, Ecol. Monogr., 48, 95-110, 1978.

Campbell, C., D. H. Vitt, L. A. Halsey, I. D. Campbel, M. N. Thormann, and S. E. Bayley, Net primary production and standing biomass in northern continental wetlands, Inf. Rep. NOR-X-369, Can. For. Serv., Edmonton, Alberta, Canada, 2000.

Carroll, P. J., and P. M. Crill, Carbon balance of a temperate poor fen, Global Biogeochem. Cycles, 11, 349-356, 1997.

Clein, J. S., and J. P. Schimel, Microbial activity of tundra and taiga soils at sub-zero temperatures, Soil Biol. Biochem., 27, 1231-1234, 1995.

Clymo, R. S., Models of peat growth, Suo, 43, 127-136, 1992.

Clymo, R. S., J. Turunen, and K. Tolonen, Carbon accumulation in peatland, Oikos, 81, 368-388, 1998.

Comer, N. T., P. M. Lafleur, N. T. Roulet, M. G. Letts, M. Skarupa, and D. Verseghy, A test of the Canadian Land Surface Scheme (CLASS) for a variety of wetland types, Atmos. Oceans, 38, 161-179, 2000.

Conrad, R., Control of methane production in terrestrial ecosystems, in Exchange of Trace Gases Between Terrestrial Ecosystems and the Atmosphere, edited by M. O. Andraea and D. S. Schimel, pp. 39-58, John Wiley, New York, 1989.

Denny, M. W., Air and Water: The Biology and Physics of Life's Media, 341 pp, Princeton Univ. Press, Princeton, N.J., 1993.

Environment Canada, Climate Normals in Canada, 1961-1990, 157 pp., Atmos. Environ. Serv., Ottawa, 1993.

Fraser, C. J. D., The hydrology and dissolved organic carbon (DOC) biogeochemistry in a boreal peatland, M.Sc. thesis, 68 pp., McGill University, Montreal, Quebec, 1999.

Fraser, C. J. D., N. T. Roulet, and T. R. Moore, Hydrology and dissolved organic carbon biogeochemistry in an ombrotrophic bog, Hydrol. Processes, 15, 3151-3166, 2001

Frolking, S., Sensitivity of spruce/moss boreal forest net ecosystem productivity to seasonal anomalies in weather, J. Geophys. Res., 102, 29,05329,064, 1997.

Frolking, S., and P. M. Crill, Climate controls on temporal variability of methane flux from a poor fen in southeastern New Hampshire: Measurement and modeling, Global Biogeochem. Cycles, 8, 385-397, 1994.

Frolking, S., et al., Modelling temporal variability in the carbon balance of a spruce/moss boreal forest, Global Change Biol., 2, 343-366, 1996.

Frolking, S., et al., Relationship between ecosystem productivity and photosynthetically active radiation for northern peatlands, Global Biogeochem. Cycles, 12, 115-126, 1998

Frolking, S., N. T. Roulet, T. R. Moore, P. J. H. Richard, M. Lavoie, and
S. D. Muller, Modeling northern peatland decomposition and peat accumulation, Ecosystems, 4, 479-498, 2001.

Gorham, E., Northern peatlands: Role in the carbon cycle and probable responses to climatic warming, Ecol. Appl., 1, 182-195, 1991.

Gorham, E., The biogeochemistry of northern peatlands and its possible response to global warming, in Biotic Feedbacks in the Global Climatic System: Will the Warming Speed the Warming?, edited by G. M. Woodwell and F. T. MacKenzie, pp. 169-187, Oxford Univ. Press, New York, 1995.

Granberg, G., Environmental control of methane emission from boreal mires, Ph.D. dissertation, 138 pp., Swed. Univ. of Agric. Sci., Umeå, Sweden, 1998.

Granberg, G., C. Mikkelä, I. Sundh, B. H. Svensson, and M. Nilsson, Sources of spatial variation in methane emission from mires in northern Sweden: A mechanistic approach in statistical modeling, Global Biogeochem. Cycles, 11, 135-150, 1997.

Granberg, G., H. Grip, M. O. Löfvenius, I. Sundh, B. H. Svensson, and M. Nilsson, A simple model for simulation of water content, soil frost, and soil temperatures in boreal mixed mires, Water Resour. Res., 35, 3771-3782, 1999.

Hadley, J. L., Effect of daily minimum temperature on photosynthesis in eastern hemlock (Tsuga Canadensis L.) in autumn and winter, Arct. Alp. Res., 32, 374-386, 2000.

Halsey, L. A., D. H. Vitt, S. C. Zoltai, and H. C. Stevens, Wetlands of Manitoba: A 1:1,000,000 summary map, Geol. Surv. of Manit., Winnipeg, Manit., Canada, 1995.

Hilbert, D., N. T. Roulet, and T. R. Moore, Modelling and analysis of peatlands as dynamic systems, J. Ecol., 88, 230-242, 2000.

Hogg, E. H., Decay potentials of hummock and hollow Sphagnum peats at different depths in a Swedish raised bog, Oikos, 66, 269-278, 1993.

Johnson, L. C., and A. W. H. Damman, Decay and its regulation in Sphagnum peatlands, Adv. Bryol., 5, 249 -296, 1993

Joyal, R., Description de la tourbière à Sphaignes Mer Bleue près d'Ottawa, 1, Végétation, Can. J. Bot., 48, 1405-1418, 1970.

Kattenberg, A., F. Giorgi, H. Grassl, G. A. Meehl, J. F. B. Mitchell, R. J. Stouffer, T. Tokioka, A. J. Weaver, and T. M. L. Wigley, Climate models: Projections of future climate, in Climate Change 1995, edited by J. T. Houghton et al., pp. 285-357, Cambridge Univ. Press, New York, 1996. Lafleur, P. M., N. T. Roulet, and S. W. Admiral, The annual cycle of $\mathrm{CO}_{2}$ exchange at a boreal bog peatland, J. Geophys. Res., 106, 3071-3081, 2001.

Lambers, H., F. S. Chapin III, and T. L. Pons, Plant Physiological Ecology, Springer-Verlag, New York, 1998.

Letts, M. G., N. T. Roulet, N. T. Comer, M. R. Skarupa, and D. Verseghy, Parameterization of peatland hydraulic properties for the Canadian Land Surface Scheme, Atmos. Oceans, 38, 141-160, 2000

Linn, D. M., and J. W. Doran, Effect of water-filled pore space on carbon dioxide and nitrous oxide production in tilled and non-tilled soils, Soil Sci. Soc. Am. J., 48, 1267-1272, 1984.

Longton, R. E., The Biology of Polar Bryophytes and Lichens, 391 pp., Cambridge Univ. Press, New York, 1988.

Milne, A. K., G. Horn, and M. Finlayson, Monitoring wetlands inundation patterns using RADARSAT multitemporal data, Can. J. Remote Sens., $26,133-141,2000$

Moore, T. R., J. L. Bubier, S. Frolking, and N. T. Roulet, Plant biomass and production and $\mathrm{CO}_{2}$ exchange in an ombrotrophic bog, J. Ecol., 90, $25-$ 36,2002 .

Mott, R. J., and M. Camfield, Palynological studies in the Ottawa area, Pap. 69-38, Geol. Surv. of Can., Ottawa, 1969

Potter, C., An ecosystem simulation model for methane production and emission from wetlands, Global Biogeochem. Cycles, 11, 495-506, 1997.

Potter, C. M., J. L. Bubier, P. M. Crill, and P. Lafleur, Ecosystem modeling of methane and carbon dioxide fluxes for boreal forest sites, Can. J. For Res., 31, 208-223, 2001

Prather, M., R. Derwent, D. Ehhalt, P. Fraser, E. Sanhueza, and X. Zhou, Other trace gases and atmospheric chemistry, in Climate Change 1994 edited by J. T. Houghton et al., pp. 77-126, Cambridge Univ. Press, New York, 1995.

Price, A. G., K. Dunham, T. Carleton, and L. Band, Variability of water flux through the black spruce (Picea mariana) canopy and feather moss (Pleurozium schreberi) carpet in the boreal forest of Northern Manitoba, J. Hydrol., 196, 310-323, 1997.

Remier, A., Role of bog plants in the exchange of carbon and water between the atmosphere and the Mer Bleue peatland, M.Sc. thesis, $88 \mathrm{pp}$. McGill Univ., Montreal, Quebec, 2001.

Rivers, J. S., D. I. Siegel, L. S. Chasar, J. P. Changton, P. H. Glaser, N. T. Roulet, and J. M. McKenzie, Stochastic appraisal of the annual carbon 
budget of a large circumboreal peatland, Rapid River Watershed, northern Minnesota, Global Biogeochem. Cycles, 12, 715-727, 1998.

Ross, J., Radiative transfer in plant communities, in Vegetation and the Atmosphere, vol. 1, edited by J. L. Monteith, pp. 13-55, Academic, San Diego, Calif., 1975.

Rothfuss, F., and R. Conrad, Development of gas diffusion probe for determination of methane concentrations and diffusion characteristics in flooded paddy soil, FEMS Microbiol. Ecol., 14, 307-318, 1994.

Roulet, N. T., D. S. Munro, and L. Mortsch, Wetlands, in The Surface Climates of Canada, edited by W. G. Bailey et al., pp. 149-171, McGill-Queen's Univ. Press, Montreal, Que., Canada, 1997.

Ryan, M. G., Effects of climate change on plant respiration, Ecol. Appl., 1, $157-167,1991$

Ryan, M. G., S. T. Gower, R. M. Hubbard, R. H. Waring, L. H. Gholz, W. P. Cropper, and S. W. Running, Woody tissue maintenance respiration of four conifers in contrasting climates, Oecologia, 101, 133-140, 1995.

Scanlon, D., and T. R. Moore, $\mathrm{CO}_{2}$ production from peatland soil profiles: The influence of temperature, oxic/anoxic conditions and substrate, Soil Sci., 165, 153-160, 2000

Silvola, J., $\mathrm{CO}_{2}$ dependence of photosynthesis in certain forest and peat mosses and simulated photosynthesis at various actual and hypothetical $\mathrm{CO}_{2}$ concentrations, Lindbergia, 11, 86-93, 1985.

Silvola, J., Combined effects of varying water content and $\mathrm{CO}_{2}$ concentration on photosynthesis in Sphagnum fuscum, Holarctic Ecology, 13, $224-228,1990$

Skre, O., W. C. Oechel, and P. M. Miller, Moss leaf water content and solar radiation at the moss surface in a mature black spruce forest in central Alaska, Can. J. For. Res., 13, 868-869, 1983.

Small, E., Photosynthetic rates in relation to nitrogen recycling as an adaptation to nutrient deficiency in peat bog plants, Can. J. Bot., 50, $2227-$ 2233, 1972.

Smith, R. A. H., and G. I. Forrest, Field estimates of primary production, in Production Ecology of British Moors and Montane Grasslands, edited by O. W. Heal and D. F. Perkins, pp. 17-37, Springer-Verlag, New York, 1978.

Sveinbjörnsson, B., Arctic treeline in a changing climate, in Arctic Ecosystems in a Changing Climate, An Ecophysiological Perspective, edited by F. S. Chapin et al., pp. 239 -256, Academic, San Diego, Calif., 1992.

Thormann, M. N., and S. E. Bayley, Above-ground net primary production along a bog-fen-marsh gradient in southern boreal Alberta, Canada, Ecoscience, 4, 374-384, 1997.

Titus, J. E., and D. J. Wagner, Carbon balance for two Sphagnum mosses:
Water balance resolves a physiological paradox, Ecology, 65, 17651774, 1984

Tolonen, K., H. Vasander, A. W. H. Damman, and R. S. Clymo, Preliminary estimate of long-term carbon acccumulation and loss in 25 boreal peatlands, Suo, 43, 277-280, 1992.

Trumbore, S. E., J. L. Bubier, J. W. Harden, and P. M. Crill, Carbon cycling in boreal wetlands: A comparison of three approaches, J. Geophys. Res., $104,27,673-27,682,1999$.

Turunen, J., E. Tomppo, K. Tolonen, and A. Reinikainen, Estimating carbon accumulation rates of undrained mires in Finland: Application to boreal and subarctic regions, Holocene, 12, 69-80, 2002.

Valentini, R., et al., Respiration as the main determinant of carbon balance in European forests, Nature, 404, 861-865, 2000.

Verseghy, D. L., The Canadian Land Surface Scheme (CLASS), its history and future, Atmos. Ocean, 38, 1-13, 2000.

Villiers, T. A., Dormancy and the Survival of Plants, 66 pp., Edward Arnold, London, 1975

Vitt, D. H., L. Halsey, and M. Thormann, The wetlands of Alberta: A 1:1,000,000 summary map, 2nd ed. with rev., Alberta Environ. Prot. Agency, Edmonton, Alberta, Canada, 1997.

Walter, B. P., and M. Heimann, A process-based, climate-sensitive model to derive methane emissions from natural wetlands: Application to five wetland sites, sensitivity to model parameters, and climate, Global Biogeochem. Cycles, 14, 745-766, 2000.

Williams, T. G., and L. B. Flannagan, Effect of changes in water content on photosynthesis, transpiration, and discrimination against ${ }^{13} \mathrm{CO}_{2}$ and $\mathrm{C}_{18} \mathrm{O}_{16} \mathrm{O}$ in Pleurozium and Sphagnum, Oecologia, 108, 38-46, 1996

J. L. Bubier, Department of Earth and Environment, Mount Holyoke College, 50 College Street, South Hadley, MA 01075, USA. (jbubier@ mtholyoke.edu)

P. M. Crill and S. Frolking, Institute for the Study of Earth, Oceans, and Space, University of New Hampshire, Morse Hall, Durham, NH 038243525, USA. (patrick.crill@unh.edu; steve.frolking@unh.edu)

P. M. Lafleur, Department of Geography, Trent University, 1600 West Bank Drive, P.O. Box 4800, Peterborough, Ontario K9J 7B8, Canada. (plafleur@trentu.ca)

T. R. Moore and N. T. Roulet, Department of Geography and Centre for Climate and Global Change Research, McGill University, 805 Sherbrooke Street West, Montreal, Quebec H3A 2K6, Canada. (moore@felix.geog. mcgill.ca; roulet@felix.geog.mcgill.ca) 